\title{
The Importance of Non-Diffusional Factors in Determining Photosynthesis of Two Contrasting Quinoa Ecotypes (Chenopodium quinoa Willd.) Subjected to Salinity Conditions
}

\author{
José Delatorre-Herrera $^{1, *}$, Karina B. Ruiz ${ }^{2}$ and Manuel Pinto ${ }^{3}$ \\ 1 Doctoral Program in Agriculture for Arid-Desert Environments, Faculty of Renewable Natural Resources, \\ Desert Agriculture Area, Universidad Arturo Prat, Iquique 1100000, Chile \\ 2 Facultad de Ciencias de la Salud, Universidad Arturo Prat, Iquique 2120, Chile; karuiz@unap.cl \\ 3 Plant Physiology Laboratory, Institute of Agronomic and Veterinary Sciences, Universidad de O'Higgins, \\ Rancagua 2820000, Chile; manuel.pinto@uoh.cl \\ * Correspondence: jodelato@unap.cl
}

\section{check for} updates

Citation: Delatorre-Herrera, J.; Ruiz, K.B.; Pinto, M. The Importance of Non-Diffusional Factors in Determining Photosynthesis of Two Contrasting Quinoa Ecotypes (Chenopodium quinoa Willd.) Subjected to Salinity Conditions. Plants 2021, 10, 927. https://doi.org/10.3390/ plants10050927

Academic Editors: Cataldo Pulvento and Didier Bazile

Received: 19 March 2021

Accepted: 27 April 2021

Published: 6 May 2021

Publisher's Note: MDPI stays neutral with regard to jurisdictional claims in published maps and institutional affiliations.

Copyright: (c) 2021 by the authors. Licensee MDPI, Basel, Switzerland. This article is an open access article distributed under the terms and conditions of the Creative Commons Attribution (CC BY) license (https:/ / creativecommons.org/licenses/by/ $4.0 /)$.

\begin{abstract}
The broad distribution of quinoa in saline and non-saline environments is reflected in variations in the photosynthesis-associated mechanisms of different ecotypes. The aim of this study was to characterize the photosynthetic response to high salinity $(0.4 \mathrm{M} \mathrm{NaCl})$ of two contrasting Chilean genotypes, Amarilla (salt-tolerant, salares ecotype) and Hueque (salt-sensitive, coastal ecotype). Our results show that saline stress induced a significant decrease in the $\mathrm{K}^{+} / \mathrm{Na}^{+}$ratio in roots and an increase in glycine betaine in leaves, particularly in the sensitive genotype (Hueque). Measurement of the photosynthesis-related parameters showed that maximum $\mathrm{CO}_{2}$ assimilation $\left(\mathrm{A}_{\max }\right)$ in control plants was comparable between genotypes (ca. 9-10 $\mu \mathrm{mol} \mathrm{CO} \mathrm{CO}^{-2} \mathrm{~s}^{-1}$ ). However, salt treatment produced different responses, with $A_{\max }$ values decreasing by $65.1 \%$ in the sensitive ecotype and $37.7 \%$ in the tolerant one. Although both genotypes maintained mesophyll conductance when stomatal restrictions were removed, the biochemical components of Amarilla were impaired to a lesser extent under salt stress conditions: for example, the maximum rate of ribulose-1,5-bisphosphate carboxylase/oxygenase (RubisCO; $\mathrm{V}_{\mathrm{cmax}}$ ) was not as affected in Amarilla, revealing that this enzyme has a higher affinity for its substrate in this genotype and, thus, a better carboxylation efficiency. The present results show that the higher salinity tolerance of Amarilla was also due to its ability to control non-diffusional components, indicating its superior photosynthetic capacity compared to Hueque, particularly under salt stress conditions.
\end{abstract}

Keywords: $\mathrm{Na}^{+}, \mathrm{K}^{+}, \mathrm{CO}_{2}$ assimilation; stomatal restrictions; non-diffusional; diffusional; RubisCO activity

\section{Introduction}

At present, about one-third of the world's irrigated land [1] is affected by salinity, which reduces plant growth and crop yield [2]. As the main food crops are rather sensitive to this stress, tolerance to salinity has become an important agronomical trait for breeders, physiologists, and agronomists [3]. The salinity of soils is predominantly caused by salt transported by irrigation water [4]. On the other hand, due to climate change, well water is becoming the main water resource for irrigation in many parts of the world, and several studies have indicated that this method is linked to potential risks of soil salinization [5-7]. An increase in the soil concentration of $\mathrm{Na}^{+}$and other ions, such as $\mathrm{Ca}^{2+}, \mathrm{Cl}^{-}$, and $\mathrm{K}^{+}$, causes a decrease in the soil water potential, which limits the water absorbed by roots and induces water stress [8]. Specific ion toxicities are due to the accumulation of sodium, chloride, and/or boron in the tissue of transpiring leaves to damaging levels. The accumulation of injurious ions may inhibit photosynthesis and protein synthesis, inactivate enzymes, and damage chloroplasts and other organelles [9]. Under normal physiological conditions, 
plants maintain a high cytosolic $\mathrm{K}^{+} / \mathrm{Na}^{+}$ratio. Given the difference in negative membrane potential at the plasma membrane $(-140 \mathrm{mV})$, a rise in extracellular $\mathrm{Na}^{+}$concentration will establish a large electrochemical gradient that favors the passive transport of $\mathrm{Na}^{+}$into cells through the activation of $\mathrm{K}^{+}$transporters/channels and through non-selective channels that are sensitive to $\mathrm{Ca}^{2+}$. The permeation of $\mathrm{Na}^{+}$via voltage-independent cation (VIC) channels is inhibited by an increase in extracellular $\mathrm{Ca}^{2+}$ concentration [10]. Overaccumulation of $\mathrm{Na}^{+}$in the cytosol inhibits protein synthesis, enzyme activity [1], and many photosynthetic processes $[11,12]$. Therefore, maintaining its water supply and excluding $\mathrm{Na}^{+}$from photosynthetic organs are crucial mechanisms used by tolerant plants to ensure an adequate rate of carbon fixation under salt stress [13]. It is well known that a reduction in stomatal conductance negatively affects the $\mathrm{CO}_{2}$ assimilation rate as well as the water balance in leaves $[3,14]$.

Excess salt affects plant growth due to an increase in soil osmotic pressure and interference with plant nutrition. A high salt concentration in the soil solution reduces the ability of plants to acquire water, which is referred to as the osmotic or water-deficit effect of salinity [9]. A decrease in $\mathrm{CO}_{2}$ assimilation is a widely reported effect of salt [15]. In many cases, this decrease is associated with the negative effect of salinity on diffusional mechanisms. These mechanisms depend on the gradient between the external and internal $\mathrm{CO}_{2}$ concentrations (mesophyll and chloroplasts), on the stomatal conductance in the gaseous phase $\left(g_{s}\right)$, and on the mesophyll conductance in the liquid phase $\left(g_{m}\right)$ [15-18].

However, salt also affects non-diffusional mechanisms, which are typically associated with electron transport and the activity of enzymes in carboxylation cycles; key enzymes in these processes include ribulose-1,5-bisphosphate carboxylase/oxygenase (RubisCO) [19,20] and those involved in the regeneration of ribulose-1,5-bisphosphate (RuBP) [21,22].

Most authors agree that diffusional factors are predominant in affecting the $\mathrm{CO}_{2}$ assimilation rate [15,23]. For example, Flexas et al. [24] reported that the conductance of the mesophyll in grapevine was strongly correlated with the rate of photosynthesis. In olive trees (Olea europaea), this occurs in the leaves of stressed plants with a conductance greater than $50 \mu \mathrm{mol} \mathrm{m} \mathrm{m}^{-2} \mathrm{~s}^{-1}$ [22]. According to the aforementioned study, the combined reduction in stomatal and mesophyll conductance in different salt-stressed olive cultivars increases the difference in $\mathrm{CO}_{2}$ concentration between the environment and chloroplasts. These results indicate that the low concentration of $\mathrm{CO}_{2}$ in chloroplasts caused by decreased stomatal and mesophyll conductance is the main limiting factor of photosynthesis.

Quinoa (Chenopodium quinoa Willd.) has evolved a number of adaptive responses to saline stress conditions, such as the increased elasticity of cell walls, low water potential, osmotic adjustment, reduction in the foliar area, the presence of papillae with calcium oxalate, the production of organic solutes [25-28], the adaptation of physiological functions such as photosynthesis [2,29], the regulation of the water status [29], ionic partitioning [30,31], and changes in stomatal conductance $[3,16,27]$.

There are an increasing number of studies on $\mathrm{CO}_{2}$ assimilation in quinoa $[2,16,26,32,33]$, although few have characterized the importance of diffusional and non-diffusional mechanisms. This species is particularly diverse at the genetic level [34], a consequence of its broad distribution in both saline and non-saline environments. This diversity could allow some ecotypes to thrive under saline stress conditions due to improved rates of photosynthesis [30].

Thus, it is possible to postulate that saline-tolerant ecotypes have better control of $\mathrm{CO}_{2}$ diffusion mechanisms than those that are less tolerant to this stress. Therefore, the aim of this study was to evaluate the differences in the photosynthetic processes between two contrasting quinoa ecotypes, as well as to analyze the relative importance of non-diffusional factors in the two ecotypes when subjected to salinity conditions. 


\section{Materials and Methods}

\subsection{Plant Material}

The two quinoa ecotypes used in this study, Amarilla and Hueque, have been previously characterized as tolerant and sensitive to salinity, respectively [30]. The Amarilla ecotype comes from the salt flat area in the northern highlands, and Hueque originates from the wet area at sea level in southern Chile.

Disinfected seeds ( $2 \%$ sodium hypochlorite for $7 \mathrm{~min}$ ) were germinated in $330 \mathrm{~mL}$ pots using perlite as the substrate. Pots containing 4 plants each were arranged over a tray containing water or solution nutritive and connected to it by means of a cotton wick to ensure water supply by capillarity. The plants were watered with sodium-free nutrient solution or $0 \mathrm{M}\left(0.25 \mathrm{dS} \mathrm{m}^{-1}\right)$ until the third pair of leaves developed (45 days after sowing (DAS)). At this stage, half of the pots of each ecotype were transferred to a modified Hoagland 2 solution containing $0.4 \mathrm{M} \mathrm{NaCl}\left(38.1 \mathrm{dS} \mathrm{m}^{-1}\right)$. This concentration corresponds to the $\mathrm{LD}_{50 \max }$ for quinoa, as determined previously by Delatorre-Herrera and Pinto [30]. To avoid a saline shock, $0.4 \mathrm{M} \mathrm{NaCl}$ was applied in increments of $0.1 \mathrm{M}$ per day. Control plants were irrigated with solution nutritive in a semi-hydroponic system (Schlick and Bubenheim [35], modified by Delatorre and Pinto [30]); for this purpose, filtered water with an electrical conductivity of $0.25 \mathrm{dS} \mathrm{m}^{-1}$ with a $\mathrm{pH}$ of 6 was used. When the plants developed their fourth or fifth pair of true leaves (70-75 DAS), they were placed in a shaded field, where the average temperature of the day was $20 \pm 5{ }^{\circ} \mathrm{C}$, and the maximum light intensity was $1500 \mu \mathrm{mol} \mathrm{m}^{-2} \mathrm{~s}^{-1}$ of photosynthetically active radiation (PAR).

\section{2. $\mathrm{Na}^{+}$and $\mathrm{K}^{+}$}

Sodium $\left(\mathrm{Na}^{+}\right)$and potassium $\left(\mathrm{K}^{+}\right)$contents were determined in samples of root, stems, and leaves taken from the bottom, middle, and top parts of the stem. Once collected, the material was dried at $70{ }^{\circ} \mathrm{C}$ for $48 \mathrm{~h}$ and then finely ground. $\mathrm{Na}^{+}$and $\mathrm{K}^{+}$were extracted by digesting $0.1 \mathrm{~g}$ of each sample in $15 \mathrm{~mL}$ of $0.5 \mathrm{M} \mathrm{HCl}$ for 2 days. The concentrations of $\mathrm{Na}^{+}$ and $\mathrm{K}^{+}$were determined according to the procedure described by Hunt [36] using a flame photometer (Jenway Model PFP 7, Cole Parmer, Vernon Hills, IL, USA).

\subsection{Proline and Glycine Betaine}

Proline (Pro) content was determined spectrophotometrically (Spectrophotometer, Genesys, Thermo Scientific, Waltham, MA, USA) in tissue with a dry weight of $100 \mathrm{mg}$ using the method described by Bates et al. [37]. A standard curve was constructed with proline (M.W. $115.13 \mathrm{~g} \mathrm{~mol}^{-1}$, Sigma-Aldrich, Santiago, Chile).

The content of Glycine Betaine (GB) was determined according to Grieve and Grat$\tan$ [38] but modified for quinoa. Briefly, tissue with a dry weight of $100 \mathrm{mg}$ was stirred in $4 \mathrm{~mL}$ of water for $24 \mathrm{~h}$ at $25^{\circ} \mathrm{C}$, after which it was filtered and stored at $4{ }^{\circ} \mathrm{C}$ until analysis. For the determination of quaternary compounds, $50 \mu \mathrm{L}$ samples were thawed, diluted in $50 \mu \mathrm{L}$ of $2 \mathrm{~N}$ sulfuric acid, and cooled to $0{ }^{\circ} \mathrm{C}$ for $1 \mathrm{~h}$. Then, $40 \mu \mathrm{L}$ of $\mathrm{KI}-\mathrm{I}_{2}$ reagent (15.7 g iodine and $20 \mathrm{~g} \mathrm{KI}$ in $100 \mathrm{~mL}$ of water) was added and gently stirred in a vortex. This solution was stored at $-4{ }^{\circ} \mathrm{C}$ for $16 \mathrm{~h}$, after which it was centrifuged at $10,000 \mathrm{rpm}$ for $15 \mathrm{~min}$. The supernatant was carefully removed, and the precipitate was dissolved in $1.6 \mathrm{~mL}$ of 1,2-dichloroethane, shaken vigorously by vortexing, and left to stand for $2.5 \mathrm{~h}$ at room temperature. GB content was detected at $365 \mathrm{~nm}$. The standard curve was constructed with betaine (M.W. $117.15 \mathrm{~g} \mathrm{~mol}^{-1}$, Sigma-Aldrich, Santiago, Chile).

\subsection{Determination of $\mathrm{CO}_{2}$ Assimilation \\ Gas Exchange}

Gas exchange measurements were performed between 09:00 and 15:00 using a gas exchange chamber connected to a portable infrared analyzer (Licor 6200, LI-COR, Lincoln, NE, USA). The relative humidity of the chamber ranged from $40 \%$ to $50 \%$, and the leaf temperature was $25 \pm 2{ }^{\circ} \mathrm{C}$. Measurements were made on fully expanded mature leaves (middle part of the stem). Each measurement was repeated three times on the same leaf 
(one leaf per plant and 6 plants per treatment). These measurements were taken when $50 \%$ of the plants had grown the fourth or fifth pair of true leaves (70-75 DAS).

(i) A/PFD curves

The photon flows (PFDs) used were 0, 20, 90, 120, 150, 300, 500, 700, 1200, 1500, and $2500 \mu \mathrm{mol}$ photons $\mathrm{m}^{-2} \mathrm{~s}^{-1}$. The light source was a halogen lamp, and the different PFDs were obtained by placing neutral filters between the lamp and the photosynthetic chamber.

The temperature in the photosynthetic chamber was $25 \pm 2{ }^{\circ} \mathrm{C}$. During measurements, the $\mathrm{CO}_{2}$ and the $\mathrm{O}_{2}$ concentrations in the chamber were maintained at $360 \mu \mathrm{L} \mathrm{L}^{-1}$ and $20 \%$, respectively $\left(\mathrm{CO}_{2}\right.$ and $\mathrm{O}_{2}$, certified gas, INDURA S.A, Alto Hospicio, Chile).

The gross photosynthesis rate $(\mathrm{A})$, the apparent quantum efficiency $(\Phi)$, photosynthetically active radiation (PAR), the rate of assimilation at saturating light intensity $\left(\mathrm{A}_{\max }\right)$, and mitochondrial respiration in darkness (Rd) were obtained from the A/PFD curves adjusted to a non-rectangular hyperbole-type equation, according to the procedure described by Lambers et al. [39]. The straight section of the curve was adjusted to a polynomial equation whose intersection on the $x$-axis corresponds to the light compensation point, and the slope is the apparent quantum yield.

(ii) $\mathrm{A} / \mathrm{C}_{\mathrm{i}}$ Curves

Measurements were made at light saturation $\left(1500 \mu \mathrm{mol}\right.$ photons $\left.\mathrm{m}^{-2} \mathrm{~s}^{-1}\right)$. The relative humidity of the chamber ranged from $40 \%$ to $50 \%$, and the leaf temperature was $25 \pm 2{ }^{\circ} \mathrm{C}$. The $\mathrm{CO}_{2}$ concentrations used were 50, 350, 500, 700, 900, 1200, and $1500 \mu \mathrm{L} \mathrm{L}^{-1}$, and the assimilation response to these intensities was adjusted to the Farquhar model $[40,41]$ with PHOTOSYN software (version 1.1.2, Dundee Scientific Ltd., Dundee, UK). Parameters such as the maximum rate of RubisCO activity $\left(\mathrm{V}_{\mathrm{c}, \max }\right)$, the transport of electrons at light saturation $\left(\mathrm{J}_{\max }\right)$, and the triose phosphate transport rate (TPU) were obtained from this model, which expresses the ratio of the assimilation rate (A) to the internal concentration of $\mathrm{CO}_{2}\left(\mathrm{C}_{i}\right)$ for each of the three factors affecting assimilation.

When carboxylation is limited only by the activity of RubisCO, then $\mathrm{W}_{\mathrm{c}}$ can be described by the model developed by Farquhar et al. [40], which is based on gaseous exchange measurements.

When the transport of electrons limits photosynthesis due to the effect of RuBP regeneration, $\mathrm{W}_{\mathrm{j}}$ can be expressed according to Farquhar and Von Caemmerer [41]. The potential rate of electron transport $\left(J_{p}\right)$ was calculated using the expression developed by Harley et al. [42].

(iii) Determination of the linear transport rate of electrons

To measure photosystem II (PSII) efficiency, the IRGA 6200 chamber was adapted by introducing a Hansantech PEA modulated pulse fluorometer sensor at one end. The parameters were calculated according to the methodology described by Maxwell and Johnson [43].

Quantum yield (ФPSII) can be used to calculate the linear transport rate of electrons $(J)$, which corresponds to photosynthetic capacity in vivo, according Genty et al. [44]. A factor of 0.84 is assumed for leaf absorbance in C3 plants [45], although this absorbance may change slightly with temperature (this experiment was conducted at foliar temperatures of $\left.25 \pm 3{ }^{\circ} \mathrm{C}\right)$.

The photochemical energy used for photosynthesis or photochemical quenching (qP) and non-photochemical quenching (NPQ) were calculated using equations described by Genty et al. [44].

\subsection{Removal of Stomatal Effects}

To remove the stomatal effect on $\mathrm{CO}_{2}$ assimilation (A), the methodology described by Centritto et al. [15] was used. For this purpose, a set of $A / C_{i}$ curves were generated for both ecotypes. The procedure employed can be divided into four phases: In phase (I), stomatal restriction (R) was induced by lowering the concentration of $\mathrm{CO}_{2}$ from 350 to $50 \mu \mathrm{L} \mathrm{L}^{-1}$ and 
allowing $\mathrm{g}_{\mathrm{s}}$ to decrease to values close to $15 \mathrm{mmol} \mathrm{m}^{-2} \mathrm{~s}^{-1}$. Subsequently, in phase (II), the $\mathrm{CO}_{2}$ concentration was raised to $1500 \mu \mathrm{L} \mathrm{L}^{-1}$, and measurements of the A/Ci curve were made until $50 \mu \mathrm{L} \mathrm{L}^{-1}$. In phase (III), a CO 2 concentration of $50 \mu \mathrm{L} \mathrm{L}^{-1}$ was maintained for a minimum of $40 \mathrm{~min}$, which depended on the stomatal behavior of each ecotype and treatment; in this way, stomatal opening was activated. Phase (IV), the final phase, was initiated once stomatal conductance began to rise above $600 \mathrm{mmol} \mathrm{m}^{-2} \mathrm{~s}^{-1}$. This raised the $\mathrm{CO}_{2}$ concentration to $1500 \mu \mathrm{L} \mathrm{L}^{-1}$, and $\mathrm{A} / \mathrm{C}_{\mathrm{i}}$ was measured with no stomatal restrictions (nR). A value of $600 \mathrm{mmol} \mathrm{m}^{-2} \mathrm{~s}^{-1}$ was used based on the data of Jacobsen et al. [26], who reported a $\mathrm{g}_{\mathrm{s}}$ of $600 \mathrm{mmol} \mathrm{H}_{2} \mathrm{O} \mathrm{m}^{-2} \mathrm{~s}^{-1}$ in quinoa without water restrictions. The times used in each stage are detailed in Table 1.

Table 1. Times of application of different concentrations of environmental $\mathrm{CO}_{2}$ to induce the closure and opening of stomata.

\begin{tabular}{|c|c|c|c|c|c|c|c|}
\hline \multicolumn{2}{|c|}{ Stage I } & \multicolumn{2}{|c|}{ Stage II } & \multicolumn{2}{|c|}{ Stage III } & \multicolumn{2}{|c|}{ Stage IV } \\
\hline \multicolumn{2}{|c|}{$\begin{array}{l}\text { Initial Period } \\
\text { Closed Stomata }\end{array}$} & \multicolumn{2}{|c|}{$\begin{array}{l}\text { With Stomatal } \\
\text { Restriction (R) }\end{array}$} & \multicolumn{2}{|c|}{$\begin{array}{c}\text { Induction Period } \\
\text { Open Stomata }\end{array}$} & \multicolumn{2}{|c|}{$\begin{array}{c}\text { No Stomatal } \\
\text { Restriction (nR) }\end{array}$} \\
\hline $\begin{array}{l}\text { Time } \\
\text { min }\end{array}$ & {$\left[\mathrm{CO}_{2}\right]$} & $\begin{array}{l}\text { Time } \\
\text { min }\end{array}$ & $\begin{array}{c}{\left[\mathrm{CO}_{2}\right]} \\
\mu \mathrm{L} \mathrm{L}^{-1}\end{array}$ & $\begin{array}{l}\text { Time } \\
\text { min }\end{array}$ & $\begin{array}{c}{\left[\mathrm{CO}_{2}\right]} \\
\mu \mathrm{L} \mathrm{L}^{-1}\end{array}$ & $\begin{array}{l}\text { Time } \\
\text { mins }\end{array}$ & $\begin{array}{l}{\left[\mathrm{CO}_{2}\right]} \\
\mu \mathrm{L} \mathrm{L}^{-1}\end{array}$ \\
\hline 0 & 350 & 21 & 1500 & 107 & 50 & 152 & 1500 \\
\hline 8 & 350 & 28 & 1200 & 132 & 50 & 162 & 1200 \\
\hline \multirow[t]{7}{*}{13} & 50 & 32 & 900 & 147 & 50 & 167 & 900 \\
\hline & & 37 & 700 & & & 172 & 700 \\
\hline & & 47 & 500 & & & 177 & 500 \\
\hline & & 54 & 350 & & & 182 & 350 \\
\hline & & 60 & 200 & & & 187 & 200 \\
\hline & & 67 & 100 & & & 192 & 100 \\
\hline & & 72 & 50 & & & 204 & 50 \\
\hline
\end{tabular}

\subsection{Determination of Mesophyll Conductance $\left(g_{m}\right)$}

Mesophyll conductance $\left(\mathrm{g}_{\mathrm{m}}\right)$ was determined according to the procedure described by Harley et al. [42] using the following parameters: assimilation rate (A), light compensation point $(\Gamma)$, electron transport rate $(J)$, and dark respiration $(\mathrm{Rd})$.

\subsection{Rate Carboxylation and Electron Transport In Vivo}

The RubisCO activity rate at $\mathrm{RuBP}$ saturation $\left(\mathrm{V}_{\mathrm{c}, \mathrm{max}}\right)$, the maximum electron transport rate $\left(\mathrm{J}_{\max }\right)$, the maximum rate of assimilation at saturating $\mathrm{PFD}$, and $\mathrm{CO}_{2}\left(\mathrm{~A}_{\max }\right)$ and mitochondrial respiration in light per unit of foliar area $\left(R_{d}\right)$ were obtained using the model described by Farquhar et al. [40]. From this model, A was determined using Equation (1):

$$
\mathrm{A}=\mathrm{vc}-0.5 \mathrm{vo}-\mathrm{Rd}
$$

where vc and vo are the rates of carboxylation and oxygenation of RubisCO, respectively, and 0.5 is the stoichiometric relationship between the $\mathrm{O}_{2}$ absorbed by RuBP oxygenase and the photorespiratory evolution of $\mathrm{CO}_{2}$ [41]. Additionally, vc cannot be greater than the minimum rate of carboxylation of $\operatorname{RubisCO}\left(\mathrm{A}_{\mathrm{c}}\right)$, and the rate of electron transport limits the regeneration of $\operatorname{RuBP}\left(\mathrm{A}_{\mathrm{j}}\right)$.

\subsection{Data Analysis}

A $2 \times 2$ factorial design was used, arranged in completely randomized blocks $\left(\mathrm{B}_{\mathrm{i}}\right)$. The first factorial level was $\mathrm{NaCl}$ concentration $\left(\mathrm{C}_{\mathrm{j}}\right)(0 \mathrm{M}$ and $0.4 \mathrm{M} \mathrm{NaCl})$, and the second level was the ecotype $\left(\mathrm{A}_{\mathrm{k}}\right)$ (Amarilla and Hueque). Each treatment had 6 replications, and 
the experimental unit consisted of 2 pots, each with 4 plants (8 plants). Duncan's multiple comparison one-way analysis of variance (ANOVA) was performed using Infostat V 2016 (Universidad de Cordoba, Cordoba, Argentina) $p<0.01$ was considered significant.

\section{Results}

\subsection{Stress Indicators}

When comparing the control plants of the two ecotypes, Hueque had a higher concentration of $\mathrm{GB}$ in the roots. When exposed to $0.4 \mathrm{M} \mathrm{NaCl}$, the $\mathrm{GB}$ content increased in both ecotypes, and it was higher in Hueque. Figure 1a shows that in the salt-tolerant ecotype (Amarilla), the GB content was higher in the leaves than in the roots. In the roots, salt stress had no effect on GB content, whereas in the leaves, GB content increased significantly. The leaf/root ratio of GB content in Amarilla control plants was 3.64, while in stressed plants, it rose slightly to 4.34 , which could indicate that this ecotype is not severely stressed by high salinity. In the salt-sensitive ecotype (Hueque), the constitutive concentration of GB was also higher in the leaves than in the roots. In the roots, the salt stress caused a decrease in the GB content; in contrast, GB rose significantly in the leaves. The leaf/root ratio of GB was 2.12 in Hueque control plants and 7.95 in stressed plants, which means that the GB synthesis in leaves was more sensitive to salt signals coming from roots.
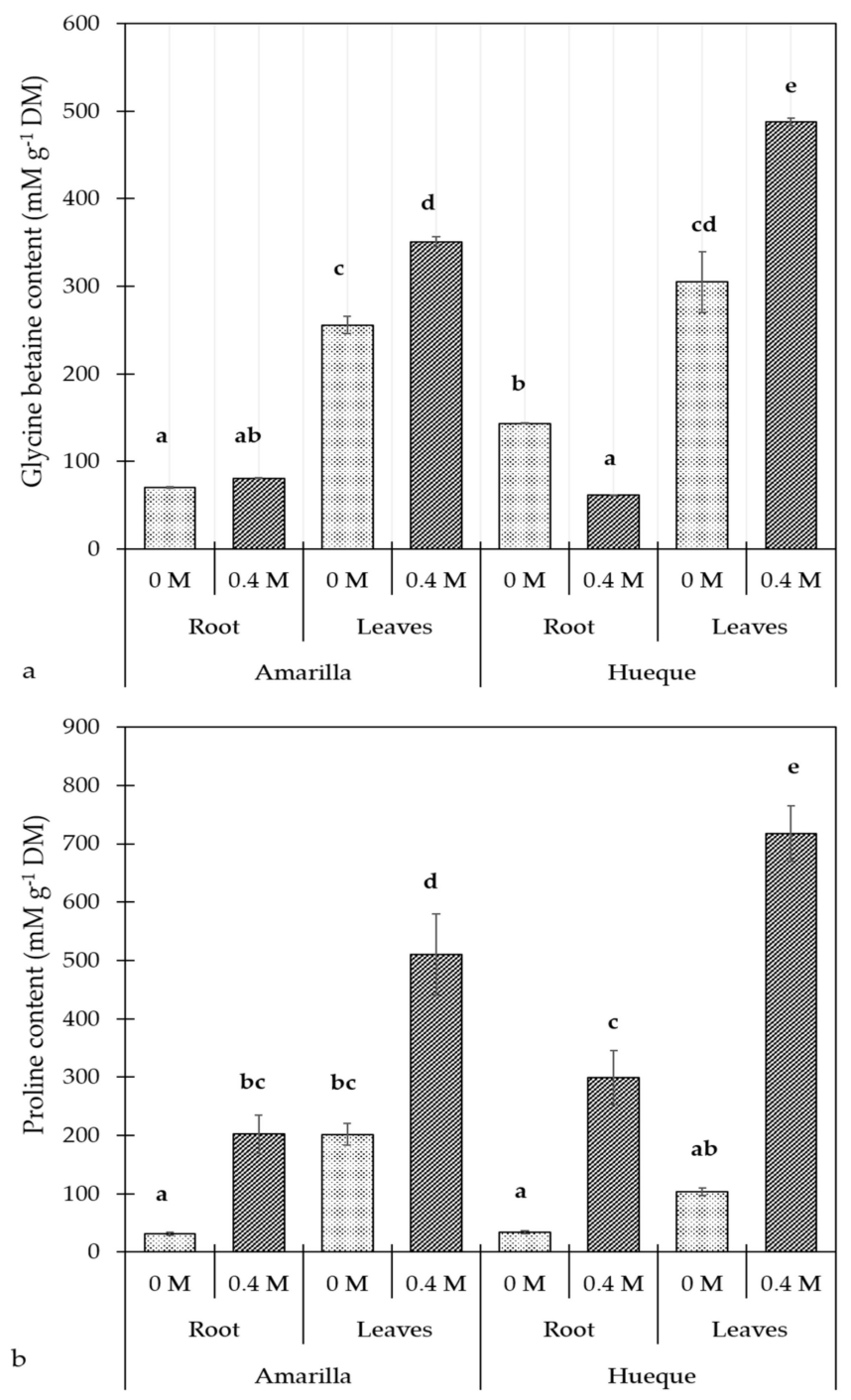

Figure 1. Effect of salinity on glycine betaine (a) and proline (b) content in the roots and leaves of quinoa plants. Different letters denote significant differences $(p \leq 0.05)$. Average values were calculated based on 4 samples per treatment (mean $\pm \mathrm{SE}$ ). 
The Pro content in the control plants did not differ much between the two ecotypes. Exposure to $0.4 \mathrm{M} \mathrm{NaCl}$ increased the Pro content in all tissues tested in both ecotypes, and it was highest in Hueque. Figure $1 \mathrm{~b}$ shows that in the tolerant ecotype, the content of Pro was significantly higher in the leaves than in the roots under both control and saline conditions. The leaf/root ratio of Pro in control plants was 6.53, and in salt-exposed plants, it fell to 2.53; this decrease was mainly due to the Pro increase in the roots. In Hueque, the content of Pro was greater in the leaves than in the roots. Applying salt did not cause changes in Pro levels in the roots, whereas in leaves, the Pro content rose significantly. The leaf/root ratio of Pro in control plants was 3.02, and when exposed to $0.4 \mathrm{M} \mathrm{NaCl}$, it was 2.40 .

\section{2. $\mathrm{Na}^{+}$and $\mathrm{K}^{+}$Content}

The tolerant ecotype accumulated in root $64.6 \%$ more $\mathrm{Na}^{+}$than the sensitive one in control conditions. Under salt stress, this difference decreased to $33 \%$ in both ecotypes because the sensitive ecotype accumulated proportionally more sodium than the tolerant one (7.4 versus 3.4 times, respectively) (Figure 2a). However, the plants showed no changes in the leaf $\mathrm{Na}^{+}$level, regardless of salt exposure. The $\mathrm{K}^{+}$content in roots was similar in the control plants of both tolerant and sensitive ecotypes and decreased significantly under salt stress. Under high concentrations of soil salt, the $\mathrm{K}^{+}$content decreased in the roots and was maintained in the leaves in both ecotypes (Figure 2b).
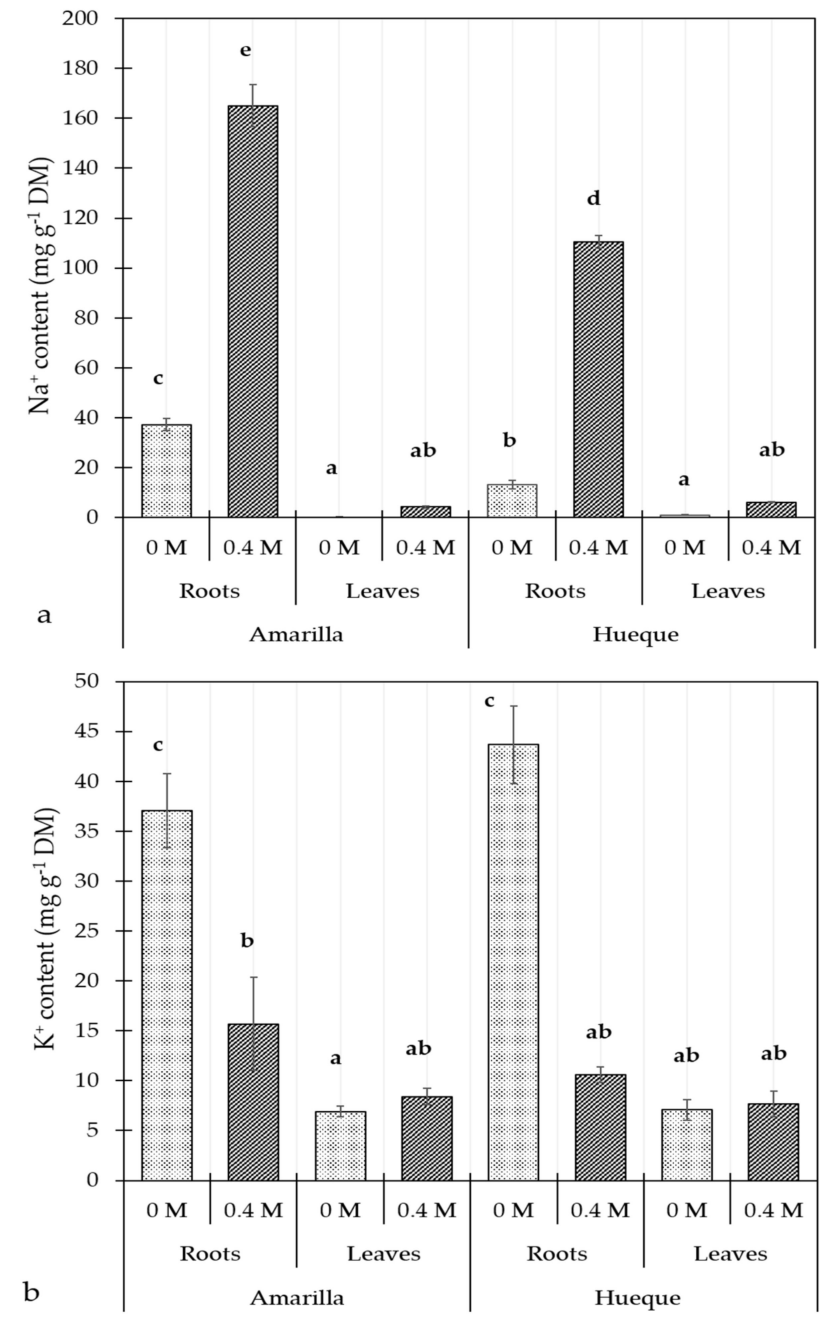

Figure 2. Effect of salinity on the content of $\mathrm{Na}^{+}(\mathbf{a})$ and $\mathrm{K}^{+}(\mathbf{b})$ in Amarilla and Hueque ecotypes of quinoa. Different letters denote significant differences $(p \leq 0.05)$. Average values were calculated based on 4 samples per treatment (mean $\pm \mathrm{SE}$ ). 


\subsection{Effect of Salinity on $\mathrm{CO}_{2}$ Assimilation under Different Light Intensities}

The A/PFD curves are shown in Figure 3. In the absence of salt stress, both ecotypes had a similar quantum yield performance and assimilation rate at light saturation. The $\mathrm{A}_{\max }$ values for Amarilla and Hueque were 9.98 and $9.05 \mu \mathrm{mol} \mathrm{CO}_{2} \mathrm{~m}^{-2} \mathrm{~s}^{-1}$, respectively (Table 2). However, the intensities at which light saturation reached were significantly different between the ecotypes: $\mathrm{CO}_{2}$ assimilation saturated at $957 \mathrm{PAR} \mu \mathrm{m}^{-2} \mathrm{~s}^{-1}$ in Hueque and at $1262 \mu \mathrm{mol} \mathrm{PAR} \mathrm{m}^{-2} \mathrm{~s}^{-1}$ in Amarilla (Table 2).

Table 2. The effect of salinity on different photosynthetic values of Amax and $g_{s}$ were obtained from curves of Figure 3 determined at the light saturation point and $350 \mu \mathrm{L} \mathrm{CO}_{2} \mathrm{~L}^{-1}$.

\begin{tabular}{|c|c|c|c|c|c|c|}
\hline Ecotype & $\begin{array}{c}\mathrm{NaCl} \\
\text { (M) }\end{array}$ & $\begin{array}{l}\text { Saturation Intensity } \\
\text { ( } \mu \text { moles PAR } \\
\left.m^{-2} s^{-1}\right)\end{array}$ & $\begin{array}{c}\operatorname{Amax} \\
\mu \mathrm{mol} \mathrm{CO}_{2} \\
\mathrm{~m}^{-2} \mathrm{~s}^{-1}\end{array}$ & $\begin{array}{c}\% \\
\text { Fall }\end{array}$ & $\begin{array}{c}\mathrm{g}_{\mathrm{s}} \\
\mathrm{mmol}^{-2} \mathrm{H}_{2} \mathrm{O}\end{array}$ & $\%$ Fall \\
\hline Amarilla & 0 & $1262 \mathrm{c}$ & 9.98 & & 310 & \\
\hline Amarilla & 0.4 & $685 \mathrm{ab}$ & 6.22 & 37.7 & 256 & 17.4 \\
\hline Hueque & 0 & $957 \mathrm{~b}$ & 9.05 & & 471 & \\
\hline Hueque & 0.4 & $420 \mathrm{a}$ & 3.16 & 65.1 & 201 & 57.3 \\
\hline
\end{tabular}

Under saline conditions $(0.4 \mathrm{M} \mathrm{NaCl})$, both ecotypes presented a drastic decrease in $\mathrm{CO}_{2}$ assimilation rates with respect to control plants (Figure 3). For example, the decrease in $\mathrm{A}_{\max }$ was $37.7 \%$ in the tolerant ecotype but $65.1 \%$ in the sensitive one (Table 3). On the other hand, at light intensities exceeding the corresponding light saturation point, saline conditions induced photoinhibition in both ecotypes. This was very drastic in the sensitive ecotype, in which assimilation was almost null at $2500 \mu \mathrm{mol}$ photons $\mathrm{m}^{-2} \mathrm{~s}^{-1}$ (Figure 3).

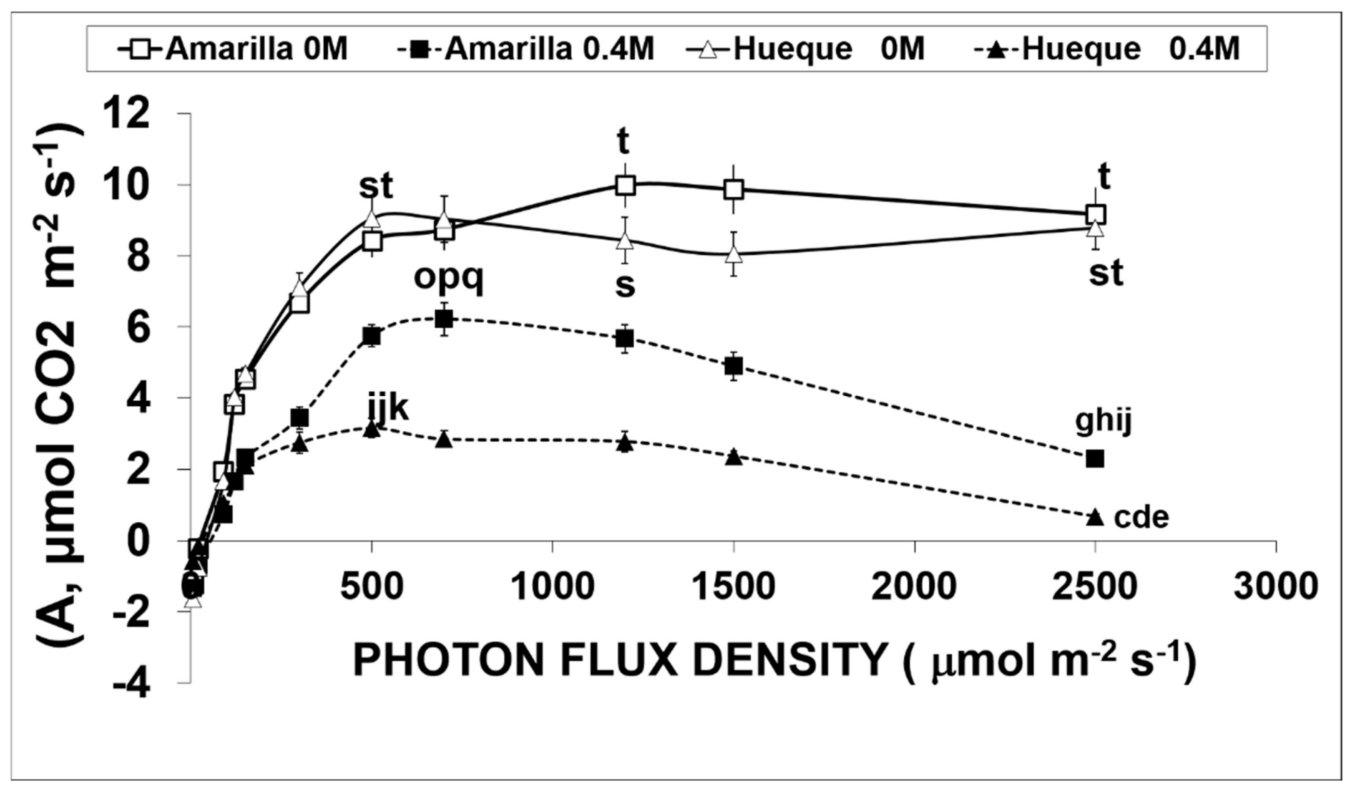

Figure 3. $\mathrm{CO}_{2}$ assimilation curves of two quinoa ecotypes subjected to salinity conditions. Empty symbols and continuous lines correspond to treatments without salt, while filled symbols with dotted lines correspond to $0.4 \mathrm{M} \mathrm{NaCl}$ treatments. Different letters denote significant differences $(p \leq 0.05)$. Average values were calculated based on 3 leaves taken from 6 plants per treatment (mean $\pm \mathrm{SE}$ ).

The analysis of the main photochemical parameters (Table 3) shows that the photochemical efficiency (ФPSII) and rate of linear electron transport (J) were negatively affected by salt stress in both ecotypes. ФPSII decreased by $18.1 \%$ for Amarilla and $29.2 \%$ for Hueque. J changed by $17.4 \%$ and $27.7 \%$ for Amarilla and Hueque, respectively. 
Table 3. Harvested energy efficiency (ФPSII) and rate of linear electron transport (J).

\begin{tabular}{cccccc}
\hline Ecotype & $\mathbf{N a C l}$ & $\boldsymbol{\Phi P S I I}$ & Significance & J & Significance \\
\hline Amarilla & $0 \mathrm{M}$ & 0.27 & $\mathrm{c}$ & 167.6 & $\mathrm{c}$ \\
\hline Amarilla & $0.4 \mathrm{M}$ & 0.22 & $\mathrm{~b}$ & 138.4 & $\mathrm{~b}$ \\
\hline Hueque & $0 \mathrm{M}$ & 0.24 & $\mathrm{bc}$ & 147.9 & $\mathrm{bc}$ \\
\hline Hueque & $0.4 \mathrm{M}$ & 0.17 & $\mathrm{a}$ & 106.9 & $\mathrm{a}$ \\
\hline${ }^{*}$ Different letters indicate significant differences $(p<0.01)$. & & &
\end{tabular}

\subsection{Determination of Non-Restrictive ( $n R$ ) and Restrictive ( $R$ ) Stomatal Conductance}

Figure 4 shows the evolution of $\mathrm{Ci}$ and $\mathrm{g}_{\mathrm{s}}$ at different timepoints, $\mathrm{CO}_{2}$ concentrations, and $\mathrm{NaCl}$ treatments for both ecotypes according to the procedure proposed by Centritto et al. [21]. This enabled us to determine the times and $\mathrm{CO}_{2}$ concentrations required to induce the rates of stomatal conductance, both restrictive $(R)$ and non-restrictive $(n R)$.

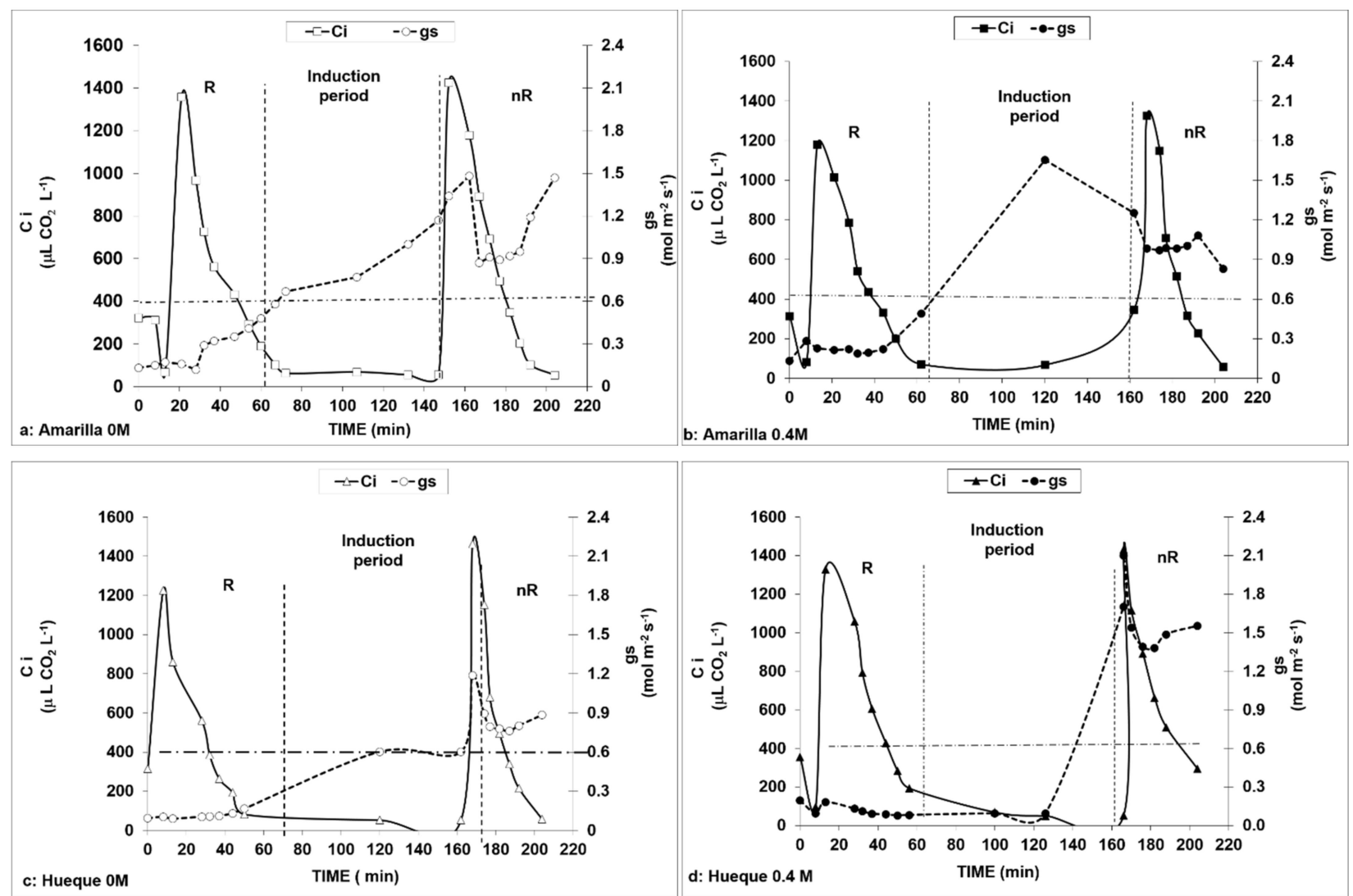

Figure 4. Curves of each ecotype used to determine the times necessary to induce stomatal opening. The continuous line represents the internal concentration of $\mathrm{CO}_{2}(\mathrm{Ci})$, and the dotted line is stomatal conductance. The line parallel to the $x$-axis represents the minimum limit required for open stomata. Lines parallel to the $y$-axis define the measurement periods. $\mathrm{R}-$ measurements with stomatal constraints; $\mathrm{nR}$-measurements with no stomatal constraints. The induction period corresponds to the time interval required to induce stomata opening by applying a concentration of $50 \mu \mathrm{L} \mathrm{CO}_{2} \mathrm{~L}^{-1}$. Internal concentrations correspond to IRGA measurements with respect to the application of a specific environmental $\mathrm{CO}_{2}$ concentration, applied according to the time sequences described in Table 1.

Once the $\mathrm{CO}_{2}$ concentration was lowered to $50 \mu \mathrm{L} \mathrm{L}^{-1}$ (phase III), the stomata opened after approximately $1.5 \mathrm{~h}(90 \mathrm{~min})$. This allowed similar stomatal conductance behaviors to be maintained between non-stress and $0.4 \mathrm{M} \mathrm{NaCl}$ conditions in both ecotypes. The maintenance of $\mathrm{Ci}$ at values equal to or less than $50 \mu \mathrm{L} \mathrm{L}^{-1}$ caused a rapid response in the tolerant ecotype in control and saline conditions (Figure $4 a, b)$. Thus, the method initially 
reduced the conductance to values close to $0.1 \mathrm{~mol} \mathrm{H}_{2} \mathrm{O} \mathrm{m}^{-2} \mathrm{~s}^{-1}$, which then increased to 1.5 and $1.6 \mathrm{~mol} \mathrm{H}_{2} \mathrm{O} \mathrm{m}^{-2} \mathrm{~s}^{-1}$ in the tolerant ecotype (at 0 and $0.4 \mathrm{M} \mathrm{NaCl}$, respectively). In Hueque, the initial value was $0.09 \mathrm{~mol} \mathrm{H}_{2} \mathrm{O} \mathrm{m}^{-2} \mathrm{~s}^{-1}$, which then increased to $1.2 \mathrm{~mol} \mathrm{H}_{2} \mathrm{O}$ $\mathrm{m}^{-2} \mathrm{~s}^{-1}$ at $0 \mathrm{M} \mathrm{NaCl}$ and $2.1 \mathrm{~mol} \mathrm{H}_{2} \mathrm{O} \mathrm{m}^{-2} \mathrm{~s}^{-1}$ at $0.4 \mathrm{M} \mathrm{NaCl}$. It was also observed that Hueque presented a higher $\mathrm{g}_{\mathrm{s}}$ as well as a greater duration of stomatal opening in saline conditions (Figure 4c,d).

These data are consistent with the assimilation rates observed in plants with stomatal restriction $(\mathrm{R})$ and without stomatal restriction (nR) (Table 4). In the salt-tolerant ecotype under control and $\mathrm{nR}$ condition, $\mathrm{A}_{\max }$ increased from 13.8 to $21.43 \mu \mathrm{mol} \mathrm{CO}_{2} \mathrm{~m}^{-2} \mathrm{~s}^{-1}$, which means that, in this case, the elimination of the stomatal restriction accounted for $55.7 \%$ of the assimilation rate. This effect was repeated in plants subjected to saline stress under the $\mathrm{nR}$ condition, but in this case, stomatal restriction accounted for only $25.4 \%$ of the increase in $A_{\max }$ (Table 4).

In the sensitive ecotype under non-salt conditions, the elimination of stomatal restriction did not induce a significant increase in $\mathrm{A}_{\max }(6.7 \%)$, which suggests that this ecotype involves another resistance mechanism, such as mesophyll resistance. However, when salt-sensitive plants were treated with salt, elimination of stomatal restriction induced a $41.2 \%$ increase in $\mathrm{A}_{\max }$. In both ecotypes, elimination of stomatal restriction induced a decrease in gross respiration under both control and salt stress conditions (Table 4).

Table 4. The effect of salinity Amax, Gross Respiration and Carboxylation efficiency parameters of tolerant and sensitive ecotypes of quinoa, obtained from A/Ci curves (Figure 5).

\begin{tabular}{|c|c|c|c|c|c|c|c|c|c|c|c|}
\hline Ecotype & $\mathrm{NaCl}$ & CONDITION & Amax & & Sig. & Gross Resp. & & Sig. & Carbox. & & Sig. \\
\hline & $\mathbf{M}$ & & $\underset{\mathrm{m}^{-2} \mathrm{~s}^{-1}}{\mu \mathrm{mol} \mathrm{CO}}$ & \pm SD & & $\underset{\mathrm{m}^{-2} \mathrm{~s}^{-1}}{\mu \mathrm{mol} \mathrm{CO}}$ & $\pm \mathrm{SD}$ & & Efic. & $\pm \mathrm{SD}$ & \\
\hline Amarilla & 0 & $\mathrm{R}$ & 13.8 & 1.03 & $\mathrm{~cd}$ & -4.09 & 1.39 & $a b$ & 0.135 & 0.036 & d \\
\hline Amarilla & 0.4 & $\mathrm{R}$ & 12.8 & 0.94 & c & -4.8 & 1.15 & $\mathrm{a}$ & 0.117 & 0.034 & d \\
\hline Amarilla & 0 & $\mathrm{nR}$ & 21.49 & 2.93 & $\mathrm{f}$ & $-2,9$ & 1.12 & $\mathrm{~cd}$ & 0.127 & 0.026 & d \\
\hline Amarilla & 0.4 & $\mathrm{nR}$ & 16.05 & 2.46 & $\mathrm{e}$ & -3.42 & 1.3 & $\mathrm{bc}$ & 0.071 & 0.033 & $\mathrm{~b}$ \\
\hline Hueque & 0 & $\mathrm{R}$ & 13.75 & 2.82 & $\mathrm{~cd}$ & -3.25 & 1.11 & $\mathrm{~cd}$ & 0.096 & 0.026 & c \\
\hline Hueque & 0.4 & $\mathrm{R}$ & 7.3 & 0.82 & $\mathrm{a}$ & -3.2 & 0.31 & $\mathrm{~cd}$ & 0.023 & 0.005 & a \\
\hline Hueque & 0 & $\mathrm{nR}$ & 14.67 & 3.2 & de & -1.95 & 0.95 & $\mathrm{e}$ & 0.07 & 0.027 & $\mathrm{~b}$ \\
\hline Hueque & 0.4 & $\mathrm{nR}$ & 10.31 & 1.62 & $\mathrm{~b}$ & -2.51 & 0.98 & de & 0.036 & 0.008 & a \\
\hline
\end{tabular}

R: with stomatal restriction; nR no stomatal restriction; Amax: Maximum assimilation rate; Gross resp.: Gross respiration (dark and photorespiration); Carbox. Efic.: Carboxylation efficiency; Different letters indicate Significance level $(p \leq 0.01)$.

The analysis of carboxylation parameters (Table 4) showed that the carboxylation efficiency in Amarilla control plants under non-restrictive stomatal conditions (nR) was not significantly altered $(p>0.05)$. However, in salt-stressed plants with $\mathrm{nR}$, carboxylation efficiency was reduced by $44.1 \%$ compared to that observed in control plants, which may be associated with the effect of mesophyll conductance $\left(\mathrm{g}_{\mathrm{m}}\right)$. In the salt-sensitive ecotype, salt stress caused decreases in carboxylation efficiency of $76 \%$ and $48 \%$ for $R$ and $n R$, respectively.

On the other hand, the unaltered maximum rates of RubisCO activity ( $\mathrm{V}_{\mathrm{cmax}}$ ) and Triose Phosphate Transport (TPU) (Table 5) indicate that, in the tolerant ecotype, the reduction in $\mathrm{CO}_{2}$ assimilation caused by salt was not due to RubisCO activity or the supply of inorganic phosphate to chloroplasts. Differently, Vcmax, TPU in Hueque fell by 36.6\% and $17.9 \%$ in $\mathrm{R}$ and $\mathrm{nR}$ conditions, respectively, showing that $\mathrm{CO}_{2}$ assimilation was affected by these factors (Table 5). 
Table 5. The effect of salinity on the main photosynthetic parameters of tolerant and sensitive ecotypes of quinoa using the model of Farquhar et al. (1980).

\begin{tabular}{|c|c|c|c|c|c|c|c|c|c|c|c|}
\hline Ecotype & $\mathrm{NaCl}$ & CONDITION & Jmax & & Sig. & Vcmax & & Sig. & TPU & & Sig. \\
\hline & $\mathbf{M}$ & & $\begin{array}{c}\mu \mathrm{mol} \mathrm{CO} \\
\mathrm{m}^{-2} \mathrm{~s}^{-1}\end{array}$ & $\pm \mathrm{SD}$ & $\begin{array}{l}p \leq \\
0.01\end{array}$ & $\underset{\mathrm{m}^{-2} \mathrm{~s}^{-1}}{\mu \mathrm{mol} \mathrm{CO}}$ & $\pm \mathrm{SD}$ & $\begin{array}{l}p \leq \\
0.01\end{array}$ & & $\pm \mathbf{S D}$ & $\begin{array}{l}p \leq \\
0.01\end{array}$ \\
\hline Amarilla & 0 & $\mathrm{R}$ & 152.66 & 62.62 & d & 32.76 & 6.41 & $\mathrm{c}$ & 10.56 & 2.77 & $\mathrm{~d}$ \\
\hline Amarilla & 0.4 & $\mathrm{R}$ & 120.53 & 20.61 & c & 29.75 & 4.57 & bc & 9.27 & 1.49 & $\mathrm{~cd}$ \\
\hline Amarilla & 0 & $\mathrm{nR}$ & 122.52 & 23.61 & c & 33.4 & 9.77 & $\mathrm{c}$ & 9.93 & 1.83 & $\mathrm{~cd}$ \\
\hline Amarilla & 0.4 & $\mathrm{nR}$ & 122.59 & 24.82 & c & 29.55 & 5.06 & $\mathrm{bc}$ & 9.69 & 1.57 & $\mathrm{~cd}$ \\
\hline Hueque & 0 & $\mathrm{R}$ & 115.15 & 24.66 & c & 27.68 & 4.94 & $\mathrm{~b}$ & 8.96 & 1.83 & $\mathrm{bc}$ \\
\hline Hueque & 0.4 & $\mathrm{R}$ & 72.29 & 13.55 & a & 18.86 & 2.72 & a & 5.68 & 1.26 & $\mathrm{a}$ \\
\hline Hueque & 0 & $\mathrm{nR}$ & 94.66 & 21.29 & $\mathrm{~b}$ & 25.67 & 6.55 & $b$ & 7.88 & 2.07 & $b$ \\
\hline Hueque & 0.4 & $\mathrm{nR}$ & 75.67 & 17.51 & a & 19.26 & 5.62 & a & 6.47 & 1.74 & a \\
\hline
\end{tabular}

R: with stomatal restriction; $\mathrm{nR}$ without stomatal restriction; Vc,max is: Maximum rate of RubisCO activity; Jmax is the transport of electrons at light saturation and TPU is triose phosphate transport rate. Different letters indicate Significance level $(p \leq 0.01)$.

The quantum efficiency of PSII ( $\Phi$ PSII) determined by the ratio of variable fluorescence (FV) and maximum fluorescence (Fm) (FV/FM) did not reveal an effect of salinity on the photochemical components of photosynthesis in either ecotype subjected to salt stress (Table 6). This means that photosystems I and II were not damaged. Therefore, it is unlikely that the decreases in the assimilation of $\mathrm{CO}_{2}$ and TPU are affected by the supply of ATP or NADPH.

Table 6. Quantum efficiency of PSII.

\begin{tabular}{cccc}
\hline ECOTYPE & M NaCl & ФPSII & Significance $^{*}$ \\
\hline Amarilla & 0 & 0.82 & $\mathrm{~b}$ \\
\hline Amarilla & 0.4 & 0.78 & $\mathrm{ab}$ \\
\hline Hueque & 0 & 0.79 & $\mathrm{ab}$ \\
\hline Hueque & 0.4 & 0.77 & $\mathrm{a}$ \\
\hline * Different letters indicate significant differences $(p<0.01)$ & &
\end{tabular}

\section{Discussion}

\subsection{Effect of Salt on Stress Indicators}

With respect to stress indicators, the present results confirm those of the previous studies in quinoa using the same or other ecotypes under similar salt conditions $[16,30,46]$. Pro accumulation has been reported in several southern Chilean quinoa accessions in response to 300 and $450 \mathrm{mM} \mathrm{NaCl}$; genotypes considered tolerant to salt stress accumulated 3-5-fold more Pro than control plants, while the more sensitive ones exhibited moderate increases [19,46-48]. Several reports on glycophytes and halophytes have indicated that accumulation of GB depends on the genotype and salt stress intensity, and a positive correlation between GB levels and salt tolerance has been reported $[49,50]$. Our results concur with these previous studies, as increases in the GB and Pro contents were observed in the leaves of both ecotypes in response to salt stress; however, in this case, it was the sensitive ecotype that presented a greater accumulation of both osmolytes. While many studies have indicated a positive relationship between GB and/or Pro accumulation and plant stress tolerance, some have argued that increases in these compounds are a product of, non- adaptive response to, salt stress [16]. In drought-stressed corn, increased ABA content was followed by an elevation in betaine aldehyde dehydrogenase (BADH) activity, leading to GB accumulation [51]. Moreover, BADH and P5CS genes, related to GB and Pro biosynthesis, respectively, were upregulated in response to treatments with salt or chromium combined with salt in quinoa [50,52,53]. In addition, exogenous applications of GB and Pro in crop species such as rice and tomato help mitigate the effects of environmental stresses, including water and salt stress [47], meaning that they may have 
a role in adaptive responses to abiotic stresses. The salt-sensitive ecotype (Hueque) had a higher constitutive concentration of GB, and under salt stress conditions, the GB content in leaves was significantly enhanced and was higher than that in Amarilla. Under saline conditions, GB biosynthesis in most plant species occurs in the chloroplast [48]. Thus, GB production may be overstimulated in leaves, thereby increasing the shoot/root ratio of GB, as observed in Hueque. In this salt-sensitive ecotype, high foliar levels of GB may contribute to the maintenance of growth by acting as a nitrogen donor [54], contributing to osmotic homeostasis [55], and protecting the plant from oxidative damage, in combination with Pro [56]. In the sensitive ecotype (Hueque), the situation seems to be similar at the root level because, while GB decreased, Pro increased to levels that were $50 \%$ higher than those in the tolerant plant, which maintained its GB content under salt stress.

Our results for $\mathrm{Na}^{+}$and $\mathrm{K}^{+}$contents agree with those reported by Adolf et al. [3] in two contrasting quinoa varieties, salt-tolerant and -sensitive, namely, Titicaca and Utusaya, respectively. They found that the $\mathrm{Na}^{+}$content in the leaves increased drastically in plants treated with $0.4 \mathrm{M} \mathrm{NaCl}$, and the increase was more pronounced in the salt-tolerant plant (Titicaca) compared to the more sensitive one (Utusaya). The significant increase found in leaf $\mathrm{Na}^{+}$content in these two genotypes could be due to the duration of salt treatment (42 days of salt treatment vs. 15 days in our experimental design).

The salt treatment also caused a significant increase in the $\mathrm{K}^{+}$concentration in the xylem of both ecotypes, but there were no differences in $\mathrm{K}^{+}$between treated and untreated plants. Our findings are similar in that there were no differences in leaf $\mathrm{K}^{+}$content between control and salt-treated plants. Our findings are similar to those reported by Orsini et al. [16] in that there were no differences in leaf $\mathrm{K}^{+}$content between control and up to $450 \mathrm{mM} \mathrm{NaCl}$ salt-treated plants of the coastal ecotype accession BO78. Potassium ions are essential for enzyme activity, protein synthesis, photosynthesis, osmoregulation, transport of phloem solutes, and the maintenance of the cation-anion balance in the cytosol and vacuoles. Recently, $\mathrm{K}^{+}$was also proposed to be a secondary messenger [57]. Thus, the ability of plants to retain $\mathrm{K}^{+}$under salt stress has emerged as an important trait for salt tolerance. By contrast, $\mathrm{Na}^{+}$is toxic in glycophytic plants, but not in halophytes [58]. Sodium ions cause multifactorial responses, such as osmotic stress $[59,60]$, the inhibition of vital enzymes [61,62], and competition with $\mathrm{K}^{+}$. Under salt stress, accumulated ions, such as $\mathrm{Na}^{+}, \mathrm{Cl}^{-}$, and $\mathrm{K}^{+}$, are used for osmotic adjustment in the aerial portions of halophytic plants [63], thus facilitating water uptake and transport and, presumably, lowering the metabolic cost required to produce large amounts of organic osmolytes, as previously described by Hariadi et al. for other quinoa genotypes [31].

At the root level, both tolerant and sensitive plants had similar responses in salinity conditions, decreasing the uptake of $\mathrm{K}^{+}$and increasing the absorption of $\mathrm{Na}^{+}$; the latter was especially pronounced in the tolerant ecotype (Amarilla). In some cases, $\mathrm{Na}^{+}$can replace $\mathrm{K}^{+}$, particularly in its osmotic functions in vacuoles under $\mathrm{K}^{+}$starvation conditions. Halophytes require less $\mathrm{K}^{+}$for growth than glycophytes [1,10], demonstrating a link between the ability to replace $\mathrm{K}^{+}$with $\mathrm{Na}^{+}$and salt tolerance [64], which is consistent with the results found in this study, in which the salt-tolerant ecotype had higher levels of $\mathrm{Na}^{+}$. In barley, a high concentration of $\mathrm{Na}^{+}$allows plants to osmotically adapt to and maintain turgor under high salinity, which is a metabolically inexpensive mechanism for osmotic adaptation. However, this new $\mathrm{Na}^{+} / \mathrm{K}^{+}$homeostasis could create a greater demand for organic solutes for osmotic adjustment, thereby compromising the energy balance of the plant [65]. In salt-tolerant barley cultivars [66], $\mathrm{K}^{+}$was reported to be the main contributor to cytoplasmic osmolality, whereas in salt-sensitive genotypes, GB and Pro compensated for reduced cytosolic $\mathrm{K}^{+}$levels.

\section{2. $\mathrm{CO}_{2}$ Assimilation and Stomatal and Mesophyll Conductance}

In both ecotypes, the decrease in $\mathrm{CO}_{2}$ assimilation due to salinity was accompanied by a decrease in stomatal conductance. However, this decrease in $g_{s}$ was greater in Hueque, (57\%, Table 2), than in Amarilla, where was only $17.4 \%$. These values are consistent with 
those reported by Centritto et al. in olive [15] and by Killi and Haworth in quinoa [2]. These authors concluded that the reduction in stomatal conductance in these species is the principal factor in reducing $\mathrm{CO}_{2}$ diffusion, inducing a decrease in the internal $\mathrm{CO}_{2}$ gas pressure and thus reducing the rate of photosynthesis. In Hueque, the magnitude of the decrease in $\mathrm{g}_{\mathrm{s}}(57.3 \%)$ due to salt treatment was proportional to the decrease in net $\mathrm{CO}_{2}$ assimilation (65.1\%). However, in Amarilla, reduction in $\mathrm{CO}_{2}$ assimilation (37.7\%) was not accompanied by a proportional reduction in $\mathrm{g}_{\mathrm{s}}(17.4 \%)$. Thus, assuming a direct relationship between $\mathrm{CO}_{2}$ assimilation and $\mathrm{g}_{\mathrm{s}}$, in the tolerant ecotype, only $46 \%$ of the reduction in $\mathrm{CO}_{2}$ assimilation caused by salt can be explained by the reduction in stomatal conductance. By contrast, in the case of Hueque, 90\% of the reduction in $\mathrm{CO}_{2}$ assimilation can be associated to the $g_{s}$ reduction. This finding suggests that in the tolerant ecotype the $\mathrm{CO}_{2}$ assimilation rate depends less on $\mathrm{g}_{\mathrm{s}}$ than in the case of the sensitive one. This in turn suggests that, in this ecotype, another diffusional mechanism may be involved in controlling $\mathrm{CO}_{2}$ assimilation, such as mesophyll conductance $\left(\mathrm{g}_{\mathrm{m}}\right)$ for example. This possibility is also supported by Bongi and Loreto [19], who indicated that $\mathrm{g}_{\mathrm{m}}$ was reduced under saline stress conditions in olive.

Despite the different behaviors of the ecotypes, $g_{s}$ was low in both when treated with $\mathrm{NaCl}$, suggesting that $\mathrm{Na}^{+}$did not interfere with $\mathrm{K}^{+}$stomatal signaling or guard cell osmoregulation [61], which is consistent with the exclusion of $\mathrm{Na}^{+}$from salt-stressed quinoa [62]. This concurs with the data shown in Figure 2, which shows that the $\mathrm{K}^{+}$content of leaves did not change under saline conditions.

Calculations of mesophyll conductance (Table 7) in control conditions indicate that at $350 \mu \mathrm{L} \mathrm{CO}_{2} \mathrm{~L}^{-1}$ and light saturation, $\mathrm{gm}_{\mathrm{m}}$ was $57 \mathrm{mmol} \mathrm{H}_{2} \mathrm{O} \mathrm{m}^{-2} \mathrm{~s}^{-1}$ in Amarilla, representing $18 \%$ of $\mathrm{g}_{\mathrm{s}}$, but was $38 \mathrm{mmol} \mathrm{H}_{2} \mathrm{O} \mathrm{m}^{-2} \mathrm{~s}^{-1}\left(<8 \% \mathrm{~g}_{\mathrm{s}}\right)$ in Hueque. This indicates that in favorable conditions, the relative importance of $\mathrm{g}_{\mathrm{m}}$ in $\mathrm{CO}_{2}$ diffusion is greater in the tolerant ecotype than in the sensitive one. However, with the application of saline stress, the $g_{m}$ values were significantly reduced in both ecotypes, falling by $49 \%$ in Amarilla (57 to $29 \mathrm{mmol} \mathrm{m}^{-2} \mathrm{~s}^{-1}$ ) and $47 \%$ (38 to $20 \mathrm{mmol} \mathrm{m}^{-2} \mathrm{~s}^{-1}$ ) in Hueque (Table 7 ). Nevertheless, these $\mathrm{g}_{\mathrm{m}}$ values only account for $11 \%$ and $10 \%$ of $\mathrm{g}_{\mathrm{s}}$, respectively, which shows that under salt stress conditions, in both ecotypes, stomatal conductance exerts much greater control over $\mathrm{CO}_{2}$ assimilation, and $\mathrm{g}_{\mathrm{m}}$ is of marginal importance.

Table 7 also shows $g_{m}$ values obtained under conditions without stomatal restriction. In both ecotypes and conditions ( $R$ and $n R)$, the increase in salinity $(0.4 \mathrm{M} \mathrm{NaCl})$ caused a reduction in $\mathrm{g}_{\mathrm{m}}$, results similar to those found by Delfine et al. [23] in spinach (Spinacia oleracea). However, after eliminating stomatal constraints under non-salt conditions, $\mathrm{g}_{\mathrm{m}}$ increased in both ecotypes, but the change was more significant in the tolerant plants (61\% in Amarilla versus 21\% in Hueque). This is consistent with Delfine et al. [23], who demonstrated that $g_{m}$ was not irreversible in olive, as we show here for quinoa [2]. On the other hand, under saline conditions and with stomatal restrictions, both ecotypes had $\mathrm{g}_{\mathrm{m}}$ values that were similar to those obtained without stomatal restriction. This finding confirms that, in quinoa, $\mathrm{g}_{\mathrm{m}}$ is not a relevant factor in determining the diffusion of $\mathrm{CO}_{2}$ in salt conditions.

Table 7. The effect of salinity on mesophyll conductance $\left(g_{\mathrm{m}}\right)$ determined at the light saturation point, with and without stomatal restriction.

\begin{tabular}{|c|c|c|c|c|c|}
\hline \multirow[t]{2}{*}{ Ecotype } & \multirow[t]{2}{*}{$\mathrm{NaCl}(\mathrm{M})$} & \multicolumn{2}{|c|}{ With Stomatal Restriction (R) } & \multicolumn{2}{|c|}{ No Stomatal Restriction (nR) } \\
\hline & & $\underset{\mathrm{mmol} \mathrm{H}_{2} \mathrm{O} \mathrm{m}_{\mathrm{m}}^{-2} \mathrm{~s}^{-1}}{\mathrm{~g}}$ & $\%$ Fall & $\underset{\mathrm{mmol} \mathrm{H}_{2} \mathrm{O} \mathrm{m}^{-2} \mathrm{~s}^{-1}}{\mathrm{~g}_{\mathrm{m}}}$ & $\%$ Fall \\
\hline Amarilla & 0 & 57 & & 92 & \\
\hline Amarilla & 0.4 & 29 & 49.0 & 32 & 65.2 \\
\hline Hueque & 0 & 38 & & 46 & \\
\hline Hueque & 0.4 & 20 & 47.4 & 20 & 56.5 \\
\hline
\end{tabular}




\subsection{Effect of Salinity on Non-Diffusional Parameters}

The effect of salinity on $\mathrm{CO}_{2}$ assimilation, measured by the internal $\mathrm{CO}_{2}$ concentration and the effect of diffusion factors, is shown in Figure $5 a, b$. In both ecotypes stomatal limitations (R) strongly affected assimilation rates, especially upon the addition of $0.4 \mathrm{M}$ $\mathrm{NaCl}$. However, the ecotypes had different responses: while A increased in Amarilla, with the removal of stomatal constraints (nR), Hueque did not show the same response. This is similar to the observations reported in Table 2, which shows that Hueque has little control over stomatal opening mechanisms, which is apparently an important factor in decreasing the $\mathrm{CO}_{2}$ assimilation rate. However, above $900 \mu \mathrm{mol} \mathrm{CO}$, Amarilla had a $\mathrm{CO}_{2}$ assimilation rate in saline conditions similar to that of control plants in unrestricted conditions. Thus, the better response of Amarilla may be due to greater photochemical efficiency and greater RubisCO activity, while in Hueque, difficulties arise as a result of diffusion and lower energy efficiency (Tables 5 and 6).
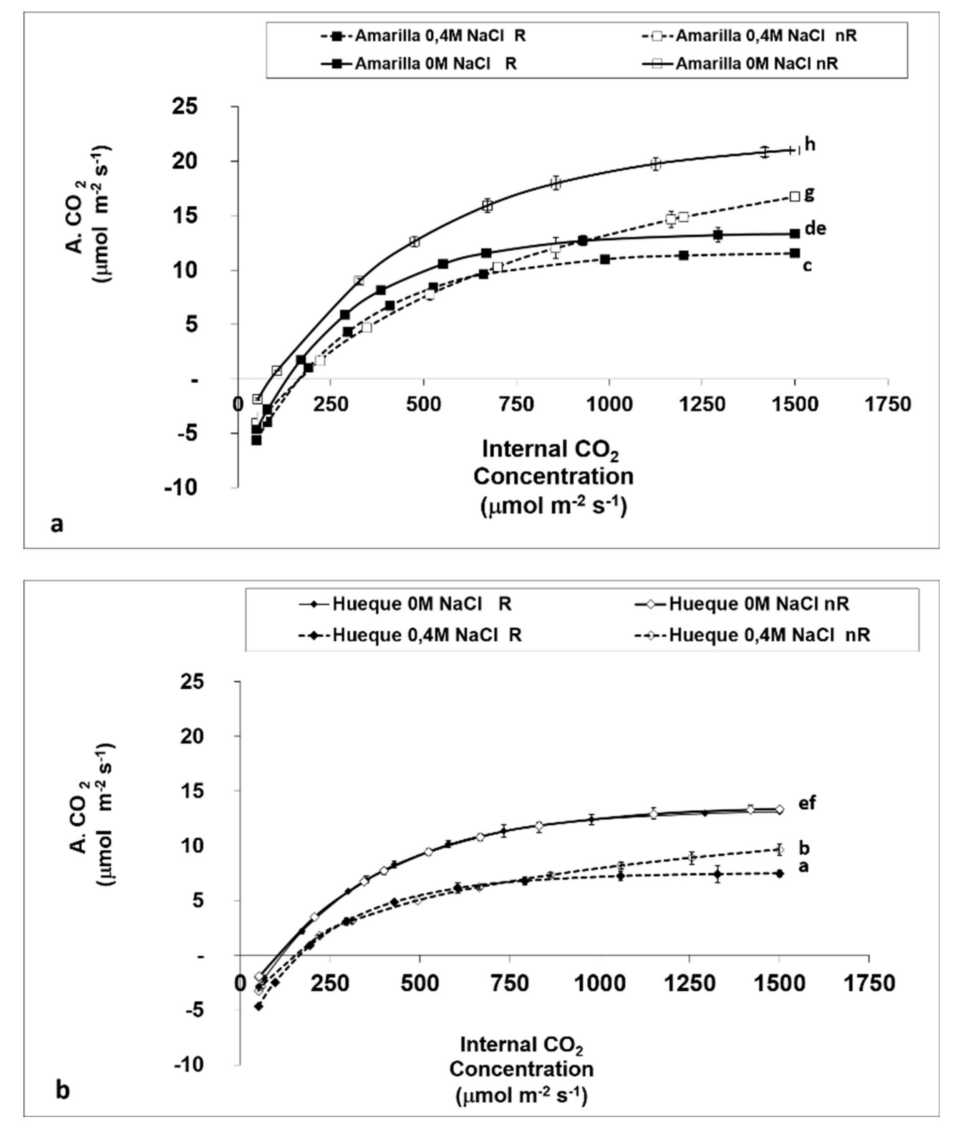

Figure 5. Evolution of $\mathrm{CO}_{2}$ assimilation based on internal $\mathrm{CO}_{2}$ concentration in the leaves of the quinoa ecotypes Amarilla (a) and Hueque (b) under limiting and non-limiting stomatal conditions. Different letters denote significant differences $(p \leq 0.01)$. Average values were calculated based on 3 leaves taken from 6 plants per treatment (mean $\pm \mathrm{SE}$ ).

The results for $\mathrm{CO}_{2}$ assimilation in both ecotypes under restrictive (R) and nonrestrictive (nR) conditions (Figure 4) indicate that, under restrictive conditions, there is little variation between salt-free and saline treatments in the tolerant ecotype (with conductance less than $300 \mathrm{mmol} \mathrm{H}_{2} \mathrm{O} \mathrm{m}^{-2} \mathrm{~s}^{-1}$ ). This result reaffirms earlier observations in this work: in the tolerant ecotype, the assimilation rate does not appear to be limited by stomatal conductance since $\mathrm{A}_{\max }$ is only reduced by $7.2 \%$. This is confirmed by the data of the $\mathrm{A} / \mathrm{Ci}$ curve under non-restrictive conditions (Figure 3). The values show an increase of $55.7 \%$ in $\mathrm{A}_{\max }$ without salt, whereas with salt, there is a smaller increase in the assimilation rate of $8.7 \%$ (Table 5). This result shows that the main limiting factor in the tolerant ecotype is non- 
diffusional. This finding, in addition to the resistance of the mesophyll, which contributes to the decrease in $\mathrm{A}$, is consistent with the first conclusions of this study (Table 2).

Table 8 shows some photochemical parameters obtained from A/PFD curves: Quantum Requirement $(\mathrm{QR})$, Light compensation points $(\mathrm{LCP})$ and Rate of dark respiration (DR). The obtained values reveal that the quantum requirement rose with salinity, and the increase was greater in Hueque (168\%) than in Amarilla (27\%). This demonstrates that salt induced a decrease in the effectiveness of photosynthesis in the sensitive ecotype, which was caused by the increase in the QR and decrease in Jmax, Vcmax, and TPU. These results are similar to those found by Killi and Haworth [2], where salinity resulted in a lower $\mathrm{Vcmax}$ of RubisCO and a lower Jmax for the regeneration of RuBP.

Table 8. Effect of salinity on the QR, LCP and DR of two quinoa ecotypes.

\begin{tabular}{|c|c|c|c|c|c|c|c|c|}
\hline \multirow{2}{*}{ Parameters } & \multicolumn{4}{|c|}{ Amarilla (Tolerant) } & \multicolumn{4}{|c|}{ Hueque (Sensitive) } \\
\hline & $\mathbf{0} \mathbf{M}$ & $0.4 \mathrm{M}$ & Difference & $\%$ & $\mathbf{0} \mathbf{M}$ & $0.4 \mathrm{M}$ & Difference & $\%$ \\
\hline $\begin{array}{l}\text { Quantum Requirement (QR) } \\
\mu \mathrm{mol} \text { photons } / \mu \mathrm{mol} \mathrm{CO}_{2}\end{array}$ & 35.2 & 44.6 & 9.43 & 27 & 28.7 & 76.9 & 48.27 & 168 \\
\hline $\begin{array}{l}\text { Light compensation } \\
\text { points(LCP) } \\
\text { Photons }\end{array}$ & 15.2 & 59.5 & 44.3 & 291 & 15.9 & 15.6 & -0.30 & -2 \\
\hline $\begin{array}{l}\text { Rate of dark respiration (DR) } \\
\qquad \mathrm{mol} \mathrm{CO} 2\end{array}$ & -0.432 & -1.33 & -0.898 & 208 & -0.553 & -0.202 & 0.351 & -63 \\
\hline
\end{tabular}

Light compensation point (LCP) also differs between the two ecotypes. Hueque shows virtually no changes with the addition of salt, which together with decreased mitochondrial respiration, could reflect the absence of mechanisms to tolerate salinity. In contrast, the tolerant increased LCP and the mitochondrial respiration, which reflect that this ecotype increases its energy requirements to activate possible mechanisms that allow it to tolerate this environmental stress. The greater tendency towards photoinhibition and the lower LCP of Hueque, reveals an acclimatization to the lower light intensities typical from the southern part of Chile, compared to the high light intensities found in northern highlands where Amarilla is acclimated. To verify this assertion, several photochemical parameters were determined. The data show that control Amarilla and Hueque plants have statistically equal quantum efficiencies. While there is a tendency to decrease $\Phi P S I I$, salt application does not cause significant changes in quantum efficiency (FV/Fm) in either ecotype with respect to its respective control.

Table 5 shows the Jmax values found in Amarilla $\left(120-152 \mu \mathrm{mol} \mathrm{m}^{-2} \mathrm{~s}^{-1}\right)$ are very similar to the average of $109 \mathrm{C}_{3}$ species $\left(134 \mu \mathrm{mol} \mathrm{m}{ }^{-2} \mathrm{~s}^{-1}\right.$; [67]) but much higher than those found by Centritto et al. [15] in olive trees $\left(79.5 \mu \mathrm{mol} \mathrm{m}^{-2} \mathrm{~s}^{-1}\right)$. Killi and Haworth [2] observed values from $72-152 \mu \mathrm{mol} \mathrm{m}^{-2} \mathrm{~s}^{-1}$ in quinoa, and significant falls in saline conditions. In our study, the salt sensitive ecotype has the lower values $\left(72-115 \mu \mathrm{mol} \mathrm{m}{ }^{-2} \mathrm{~s}^{-1}\right.$ ), demonstrating that in this ecotype exposure to saline stress causes reductions in Jmax, and that the decrease in A could also be associated with the transport of electrons. It is striking that comparing this parameter between $0 \mathrm{M}$ and $0.4 \mathrm{M} \mathrm{NaCl}$ with and without stomatal restriction produces a significant reduction in Hueque, but not in Amarilla, indicating that the difficulties in the sensitive ecotype could be due to carboxylation, given by an effect on Jmax, which would indicate a problem on the supply of ATP and NADPH. According to Killi and Haworth [2], the reductions in Vcmax found in salt-stressed quinoa would be compatible with the altered carboxylation of RubisCO [68,69] and/or by the reduced content of RubisCO [70]. Salt stress also reduced the regenerative capacity of RuBP in quinoa indicative of reduced RuBP availability [69] and expression [71,72], particularly in salinity.

In the case of Hueque, the parameters evaluated highlight that in addition to the high incidence of $\mathrm{g}_{\mathrm{s}}$ on the rate of $\mathrm{CO}_{2}$ assimilation, there is also an effect caused by RubisCO, 
which is seen by comparing carboxylation efficiencies and Vcmax, between salt and control growth conditions. Similarly, Jmax and the TPU also play a role.

The Vcmax values in Amarilla quinoa under control conditions found here were lower (29-33 $\mu \mathrm{mol} \mathrm{m}{ }^{-2} \mathrm{~s}^{-1}$ ) than those reported by Wullschleger [67] (average values of $64 \mu \mathrm{mol} \mathrm{m}{ }^{-2} \mathrm{~s}^{-1}$ for 109 species) and Killi and Haworth [2] (values from 60 to $160 \mu \mathrm{mol}$ $\mathrm{m}^{-2} \mathrm{~s}^{-1}$ in quinoa). However, the decreases in Vcmax observed in plants sensitive to saline stress in our study, as well as the results of Killi and Haworth [2] in quinoa treated with salt, indicate that differences in reported values may be associated with the particular characteristics of the different ecotypes used. The tolerant plants had higher Vcmax values than sensitive ecotypes. In this regard, Manter and Kerrigan [73] indicated that, in woody species, the values ranged between 31.2 and $42.2 \mu \mathrm{mol} \mathrm{m}^{-2} \mathrm{~s}^{-1}$ and were associated with low mesophilic conductance, similar to the two Chilean quinoa ecotypes used in our study. In addition, salinity also induced reductions in Vcmax and Jmax, corroborating the loss of photosynthetic ability. The reductions in Vcmax found in quinoa with salt stress are compatible with poor carboxylation by RubisCO $[2,69,74]$.

The ability to maintain intact membranes and photosystems may enable Amarilla to maintain photosynthesis even in saline conditions. In the cells of photosynthetic organisms, salt stress leads to a decrease in cell volume, induces osmotic stress, and inhibits the photosynthetic electron transfer process [75-77], and in Synechococcus cells, PSII and PSI are both inactivated due to changes in the $\mathrm{K}^{+} / \mathrm{Na}^{+}$ratio [76]. In our experiments, salt treatment led to a 10.5-fold reduction in the level of $\mathrm{K}^{+}$in the roots of the salt-tolerant ecotype (Amarilla) and a 34.6-fold reduction in the more sensitive ecotype (Hueque). The lower supply of this element could mean that PSII is more inactivated in Hueque than in Amarilla, as shown by the $\mathrm{CO}_{2}$ assimilation rates (Table 2), resulting in high $\mathrm{Na}^{+}$ and $\mathrm{Cl}^{-}$fluxes into cells, disrupting ion homeostasis, and leading to the accumulation of reactive oxygen species (ROS) [76,78,79], which is associated with membrane lipid peroxidation [80,81] and can adversely affect photosynthesis [81].

Control of oxidation is achieved through the synthesis of antioxidants such as polyphenols, which are divided into several subgroups, among which are the flavonoids (including flavonol glycosides and isoflavones) [82]. Tocopherol and carotenoids are known to be very important for the scavenging of lipid peroxides in Synechocystis 6803 [83]. Flavonol glycosides constitute the most abundant phenolics in quinoa seeds and leaves [84]. Several phenolic acids, including hydroxycinnamic acid and hydrobenzoic acid derivatives, have been identified in quinoa seeds and leaves [85]. Furthermore, the highest activity was observed in red-violet quinoa varieties containing both betacyanins and betaxanthins, with significant capacity/activity also exhibited by the yellow ecotype. These varieties or ecotypes are characterized by a high dopaxanthin content, whose dihydroxylated substructure is a powerful antioxidant [83]. Our results show that both ecotypes significantly increase the GB content as a mechanism to protect photosynthetic activity. Some plant varieties are able of biosynthesize GB, exhibiting a greater tolerance to abiotic stress, and often have enhanced growth and yield relative to varieties that do not accumulate GB [86]. The increased GB accumulation mainly occurs in the chloroplast and is responsible for initiating a network of interactions between the plant's photosynthetic apparatus, its "stress" and "growth" hormones, and reactive oxygen species. The increased abiotic stress tolerance of plants able to accumulate GB appears in large part to be due to the ability of chloroplastproduced GB to protect the photosynthetic apparatus [86]. In particular, the accumulation of GB in the chloroplast in response to a stress signal protects enzymes and lipids that are required to maintain both the flow of electrons through thylakoid membranes and the continued assimilation of $\mathrm{CO}_{2}[87,88]$.

It is probable that the Amarilla ecotype also has other mechanisms for membrane protection, such as the presence of trehalose [89]. Trehalose can act as a structural component when incorporated into glycolipids, thereby stabilizing membranes $[50,89,90]$. 


\section{Conclusions}

The Calvin cycle requires energy inputs that come from the photochemical phase, and the data show that electron transport is not strongly affected in the tolerant ecotype, which had higher J and Jmax values than those found in the sensitive ecotype. This allows NADPH and ATP to maintain their contributions to the production of triose phosphates (TPU), which, according to our results, do not differ from the treatment without salt. This suggests that the Amarilla ecotype maintains its rate of RuBP under salinity conditions. On the other hand, the Quantum Requirement (QR), light compensation points, and the dark respiration rate are increased, which may be the result of an adaptation of the photochemical apparatus through membrane protection, as seen by the increase in GB.

In the sensitive ecotype (Hueque), the $\mathrm{CO}_{2}$ assimilation rate was affected in both the biochemical and photochemical components; in this respect, Vcmax, TPU, Jmax, J, ФPSII, and QR dramatically decreased. Light compensation points and the dark respiration rate were not affected.

Another mechanism that was activated in the short term in response to salt treatment in both ecotypes was the exclusion of $\mathrm{Na}^{+}$towards the leaves and growth centers. Both ecotypes retained $\mathrm{Na}^{+}$in the roots and restricted its entry to the leaves. This mechanism must be associated with the compartmentalization and blocking of excess $\mathrm{Na}^{+}$not only in the vacuoles of quinoa leaves (tissue tolerance) but also in those of root cells (ion exclusion), mechanisms that are important for protection in response to ionic toxicity induced by salt at the cellular level.

Author Contributions: Conceptualization, J.D.-H. and M.P.; methodology, M.P.; formal analysis, J.D.-H.; investigation, J.D.-H.; resources, J.D.-H.; data curation, J.D.-H.; writing —original draft preparation, J.D.-H. and K.B.R.; writing - review and editing, K.B.R.; visualization, K.B.R.; supervision, M.P.; project administration, J.D.-H. All authors have read and agreed to the published version of the manuscript.

Funding: This research was funded by Doctoral Program in Desert and Arid Agriculture, Universidad Arturo Prat and project FONDEQUIP EQM1900088- ANID. K.B.R. was supported by grant PAI 79170093.

Institutional Review Board Statement: Not applicable.

Informed Consent Statement: Not applicable.

Data Availability Statement: The data presented in this study are available in this article.

Acknowledgments: We acknowledge Michael Hanford from Universidad of Chile, for providing the translation and discussion support. We kindly thank Alejandro Riquelme of Centro de Estudios Avanzados en Fruticultura. We also appreciate the valuable contributions of the reviewers of this manuscript, they have been very useful to improve its quality.

Conflicts of Interest: The authors declare no conflict of interest.

\section{References}

1. Flowers, T.J.; Colmer, T.D. Salinity tolerance in halophytes. New Phytol. 2008, 179, 945-963. [CrossRef]

2. Killi, D.; Haworth, M. Diffusive and metabolic constraints to photosynthesis in quinoa during drought and salt stress. Plants 2017, 6, 49. [CrossRef]

3. Adolf, V.I.; Shabala, S.; Andersen, M.N.; Razzaghi, F.; Jacobsen, S.E. Varietal differences of quinoa's tolerance to saline conditions. Plant Soil 2012, 357, 117-129. [CrossRef]

4. Rengasamy, P. World salinization with emphasis on Australia. Journal of Experimental Botany. Plants Salin. Spec. Issue 2006, 57, 1017-1023. [CrossRef]

5. Chen, W.; Hou, Z.; Wu, L.; Liang, Y.; Wei, C. Evaluating salinity distribution in soil irrigated with saline water in arid regions of northwest China. Agric. Water Manag. 2010, 97, 2001-2008. [CrossRef]

6. Hanson, B. Drip irrigation and salinity. Agricultural Salinity Assessment and Management. Manuals and reports on engineering practice 71 (2 edn). Am. Soc. Civ. Eng. Rest. 2012, 5, 539-560.

7. Mounzer, O.; Pedrero-Salcedo, F.; Nortes, P.A.; Bayona, J.M.; Nicolás, E.; Alarcón, J.J. Transient soil salinity under the combined effect of reclaimed water and regulated deficit drip irrigation of Mandarin trees. Agric. Water Manag. 2013, 120, 23-29. [CrossRef] 
8. Hasewaga, P.M.; Bressam, R.A.; Zhu, J.K.; Bohnert, H.J. Plant cellular and molecular response to high salinity. Ann. Rev. Plant Physiol. Plant Biol. 2000, 51, 463-499. [CrossRef] [PubMed]

9. Almeida-Machado, E.M.; Serralheiro, R.P. Soil Salinity: Effect on Vegetable Crop Growth Management Practices to Prevent and Mitigate Soil Salinization. Horticulturae 2017, 3, 30. [CrossRef]

10. Blumwald, E. Sodium transport and salt tolerance in plants. Curr. Opin. Cell Biol. 2000, 12, 431-434. [CrossRef]

11. Tsugane, K.; Kobayashi, K.; Niwa, Y.; Ohba, Y.; Wada, K.; Kobayashi, H. A recessive Arabidopsis mutant that grows photoautotrophically under salt stress shows enhanced active oxygen detoxification. Plant Cell 1999, 11, 1195-1206. [CrossRef]

12. Tsunekawa, K.; Shijuku, T.; Hayashimoto, M.; Kojima, Y.; Onai, K.; Morishita, M.; Ishiura, M.; Kuroda, T.; Nakamura, T.; Kobayashi, H.; et al. Identification and characterization of the $\mathrm{Na}+\mathrm{H}+$ antiporter Nhas3 from the Thylakoid Membrane of Synechocystis sp. PCC 68036803. J. Biol. Chem. 2009, 284, 16513-16521. [CrossRef]

13. Yamaguchi, T.; Hamamoto, S.; Uozumi, N. Sodium transport system in plant cells. Front. Plant Sci. 2013, 4, 410. [CrossRef]

14. Rivelli, A.R.; Lovelli, S.; Perniola, M. Effects of salinity on gas exchange, water relations and growth of sunflower (Helianthus annuus). Funct. Plant Biol. 2002, 29, 1405-1415. [CrossRef] [PubMed]

15. Centritto, M.; Loreto, F.; Chartzoullakis, K. The use of low $\left[\mathrm{CO}_{2}\right]$ to estimate diffusional and non-diffusional limitations of photosynthetic capacity of salt-stressed olive saplings. Plant Cell Environ. 2003, 26, 585-594. [CrossRef]

16. Orsini, F.; Accorsi, M.; Gianquinto, G.; Dinelli, G.; Antognoni, F.; Ruiz-Carrasco, K.B.; Martinez, E.A.; Alnayef, M.; Marotti, I.; Bosi, S.; et al. Beyond the ionic and osmotic response to salinity in Chenopodium quinoa functional elements of successful halophytism. Funct. Plant Biol. 2011, 138, 818-831. [CrossRef] [PubMed]

17. Flexas, J.; Bota, J.; Escalona, J.M.; Sampol, B.; Medrano, H. Effects of drought on photosynthesis in grapevines Ander field conditions: An evaluation of stomatal and mesophyll limitattions. Funct. Plant Biol. 2002, 29, 461-471. [CrossRef]

18. von Caemmere, S.; Evans, J.R. Determination of the $\mathrm{CO}_{2}$ pressure in chloroplast from leaves of several C3 plants. Aust. J. Plant Physiol. 1991, 18, 287-305.

19. Bongi, G.; Loreto, F. Gas-Exchange properties of salt stressed olive (Olea europea L.) Leaves. Plant Physiol. 1989, 90, 1408-1416. [CrossRef]

20. Lopez-Climent, M.F.; Arbona, V.; Pérez-Clemente, M.; Gómez-Cadenas, A. Relationship between salt tolerance and photosynthetic machinery performance in citrus. Environ. Exp. Bot. 2008, 62, 176-184. [CrossRef]

21. Bota, J.; Medrano, H.; Flexas, J. Is photosynthesis limited by decresed Rubisco activity and RuBP content under progressive water stress? New Phytol. 2004, 126, 671-681. [CrossRef] [PubMed]

22. Loreto, F.; Centritto, M.; Chartzoullakis, K. Photosynthetic limitations in olive cultivars with differente sensitivity to salt stress. Plant Cell Environ. 2003, 26, 595-601. [CrossRef]

23. Delfine, S.; Alvino, A.; Concetta, M.; Loreto, F. Restrictions to carbon dioxide conductance and photosynthesis in Spinach leaves recovering from salt stress. Plant Physiol. 1999, 199, 1101-1106. [CrossRef]

24. Flexas, J.; Medrano, H. Drought-inhibition of Photosynthesis in C3 Plants: Stomatal and Non-stomatal Limitations Revisited. Ann. Bot. 2002, 89, 183-189. [CrossRef]

25. Orrego, M.; Riquelme, A. Efecto de la Concentración de Sodio(Na+) Sobre Algunos Parámetros Hídricos y Fenología de la Quinua (Chenopodium quinoa Willd); Tesis para optar al Título de Ingeniero de Ejecución Agrícola. Pregrado, Universidad Arturo Prat: Iquique, Chile, 2012.

26. Jacobsen, S.E.; Mujica, A.; Jensen, C.R. The resistance of quinoa (Chenopodium quinoa Willd.) to adverse abiotic factors. Food Rev. Int. 2003, 19, 99-109. [CrossRef]

27. Bosque, H.; Lemeur, P.; Van Damme, P.; Jacobsen, S.E. Ecophysiological Analysis of drought and salinity stress of quinoa (Chenopodium quinoa Willd). Food Rev. Int. 2003, 19, 11-19.

28. Ruffino, A.M.C.; Rosa, M.; Hilal, M.; González, J.A.; Prado, F.E. The role of cotyledon metabolism in the establishment of quinoa (Chenopodium quinoa) seedlings growing under salinity. Plant Soil 2010, 326, 213-224. [CrossRef]

29. Jensen, C.R.; Jacobsen, S.-E.; Andersen, M.N.; Núñez, N.; Andersen, S.D.; Rasmussen, L.; Mogensen, V.O. Leaf gas exchange and water relation characteristics of field quinoa (Chenopodium quinoa Willd.) during soil drying. Eur. J. Agron. 2000, 13, 11-25. [CrossRef]

30. Delatorre-Herrera, J.; Pinto, M. Importance of ionic and osmotic componets of salt stress on the germination of four quinua (Chenopodium quinoa Willd.) selections. Chil. J. Agric. Res. 2009, 69, 477-485. [CrossRef]

31. Hariadi, Y.; Marandon, K.; Tian, Y.; Jacobsen, S.E.; Shabala, S. Ionic and osmotic relations in quinoa (Chenopodium quinoa Willd.) plants grown at various salinity levels. J. Exp. Bot. 2011, 62, 185-193. [CrossRef] [PubMed]

32. Razzaghi, F.; Jacobsen, S.E.; Jensen, C.R.; Andersen, M.N. Ionic and photosynthetic homeostasis in quinoa challenged by salinity and Drought-Mechanisms of tolerance. Funct. Plant Biol. 2015, 42, 136-148. [CrossRef]

33. Geissler, N.; Mervat, S.H.; El-Far, M.M.; Koyro, H.-W. Elevated atmospheric $\mathrm{CO}_{2}$ concentration leads to different salt resistance mechanisms in a C3 (Chenopodium quinoa) and a C4 (Atriplex nummularia) halophyte. Environ. Exp. Bot. 2015, 118, 67-77. [CrossRef]

34. Maughan, P.J.; Bonifacio, A.; Jellen, E.N.; Stevens, M.R.; Coleman, C.E.; Ricks, M.; Mason, S.L.; Jarvis, D.E.; Gardunia, B.W.; Fairbanks, D.J. A genetic linkage map of quinoa (Chenopodium quinoa) based on AFLP, RAPD, and SSR markers. Appl. Genet. 2004, 109, 1188-1195. [CrossRef]

35. Schlink, G.; Bubenheim, D. Quinoa crop NASA's Controlled Ecological Life Support Systems. In Progress in New Crops; ASHS Press: Arlington, VA, USA, 1996; pp. 632-640. ISBN 0961502738. 
36. Hunt, J. Dilute hydrochloric acid extraction of plant material for routines cation analysis. Commun. Soil Sci. Planta Anal. 1982, 13, 49-55. [CrossRef]

37. Bates, L.S.; Waldren, R.P.; Teare, I.D. Rapid determination of free proline for water-stress studies. Plant Soil 1973, 39, 205-207. [CrossRef]

38. Grieve, C.M.; Grattan, S.R. Rapid assayfor determination of water soluble quaternary ammonium compounds. Plant Soli 1983, 70, 303-307. [CrossRef]

39. Lambers, H.; Chapin, F.S.; Pons, T.L. Plant Physiological Ecology; Springer: New York, NY, USA, 2008; p. 624. ISBN 978-0-38778340-6. [CrossRef]

40. Farquhar, G.D.; Von Caemmerer, S.; Berry, J.A. A biochemical model of photosynthetic $\mathrm{CO}_{2}$ assimilation in leaves of C3 species. Planta 1980, 149, 78-90. [CrossRef]

41. Farquhar, G.D.; Von Caemmerer, S. Modelling of photosynthetic responses to environmental conditions. In Physiological Plant Ecology II. Water Relations and Carbon Assimilation; Lange, O.L., Nobel, P.S., Osmond, C.B., Ciegler, H., Eds.; Springer: Berlin, Germany, 1982; pp. 549-587.

42. Harley, P.C.; Loreto, F.; Di Marco, G.; Sharkey, T.D. Theoretical considerations when estimating the mesophyll conductance to $\mathrm{CO} 2$ flux by analysis of the response of photosynthesis to $\mathrm{CO}_{2}$. Plant Physiol. 1992, 98, 1429-1436. [CrossRef] [PubMed]

43. Maxwell, K.; Johnson, G.N. Chlorophyll fluorescence-A practical guide. J. Exp. Bot. 2000, 51, 659-668. [CrossRef]

44. Genty, B.; Briantais, J.-M.; Baker, N.R. The relationship between the quantum yield of photosynthetic electron transport and quenching of chlorophyll fluorescence. Biochim. Biophys. Acta BBA Gen. Subj. 1989, 990, 87-92. [CrossRef]

45. Björkman, O.; Demmig, B. Photon yield of O2 evolution and chlorophyll fluorescence characteristics at $77 \mathrm{~K}$ among vascular plants of diverse origins. Planta 1987, 170, 489-504. [CrossRef] [PubMed]

46. Ruiz-Carrasco, K.; Antognoni, F.; Coulibaly, A.K.; Lizardi, S.; Covarrubias, A.; Martínez, E.A.; Molina-Montenegro, M.A.; Biondi, S.; Zurita-Silva, A. Variation in salinity tolerance of four lowland genotypes of quinoa (Chenopodium quinoa Willd.) as assessed by growth, physiological traits, and sodium transporter gene expression. Plant Physiol. Biochem. 2011, 49, 1333-1341. [CrossRef]

47. Ashraf, M.; Foolad, M.R. Roles of glycine betaine and proline in improving plant abiotic stress resistance. Environ. Exp. Bot. 2007, 59, 206-216. [CrossRef]

48. Habib, N.; Ashraf, M.; Ali, Q.; Perveen, R. Response of salt stressed okra (Abelmoschus esculentus Moench) plants to foliar-applied glycine betaine and glycine betaine containing sugarbeet extract. S. Afr. J. Bot. 2012, 83, 151-158. [CrossRef]

49. Zhao, Y.; Ma, Y.Q.; Weng, Y.J. Variation of betaine and proline contents in wheat seedlings under salt stress. J. Plant Physiol. Mol. Biol. 2005, 31, 103-106.

50. Morales, A.J.; Bajgain, P.; Garver, Z.; Maughan, P.J.; Udall, J.A. Physiological responses of Chenopodium quinoa to salt stress. Int. J. Plant Physiol. Biochem. 2011, 3, 219-232.

51. Zhang, L.; Gao, M.; Hu, J.; Zhang, X.; Wang, K.; Ashraf, M. Modulation role of abscisic acid (ABA) on growth, water relations and glycinebetaine metabolism in two maize (Zea mays L.) cultivars under drought stress. Int. J. Mol. Sci. 2012, 13, 3189-3202. [CrossRef] [PubMed]

52. Ruiz, K.B.; Rapparini, F.; Bertazza, G.; Silva, H.; Torrigiani, P.; Biondi, S. Comparing salt-induced responses at the transcript level in a salares and coastal-lowlands landrace of quinoa (Chenopodium quinoa Willd). Environ. Exp. Bot. 2017, 139, 127-142. [CrossRef]

53. Guarino, F.; Ruiz, K.B.; Castiglione, S.; Cicatelli, A.; Biondi, S. The combined effect of Cr (III) and NaCl determines changes in metal uptake, nutrient content, and gene expression in quinoa (Chenopodium quinoa Willd.). Ecotoxicol. Environ. Saf. 2000, 193, 110345. [CrossRef]

54. Carillo, P.; Mastrolonardo, G.; Nacca, F.; Parisi, D.; Verlotta, A.; Fuggi, A. Nitrogen metabolism in durum wheat under salinity: Accumulation of proline and glycine betaine. Funct. Plant Biol. 2008, 35, 412-426. [CrossRef]

55. Flowers, T.J.; Troke, P.F.; Yeo, A.R. The mechanism of salt tolerance in halophytes. Annu. Rev. Plant Physiol. 1997, $28,89-121$. [CrossRef]

56. Annunziata, M.G.; Ciarmiello, L.F.; Woodrow, P.; Dell'Aversana, E.; Carillo, P. Spatial and Temporal Profile of Glycine Betaine Accumulation in Plants Under Abiotic Stresses. Front. Plant Sci. 2019, 10, 230. [CrossRef] [PubMed]

57. Shabala, S. Signalling by potassium: Another second messenger to add to the list. J. Exp. Bot. 2017, 68, 4003-4007. [CrossRef]

58. Shabala, S.; Hariadi, Y.; Jacobsen, S.-E. Genotypic difference in salinity tolerance in quinoa is determined by differential control of xylem Na+ loading and stomatal density. J. Plant Physiol. 2013, 170, 906-914. [CrossRef] [PubMed]

59. Tarczynsk, M.C.; Jensen, R.G.; Bohnert, H.J. Stress Protection of Transgenic Tobacco by Production of the Osmolyte Mannitol. Science 1993, 259, 508-510. [CrossRef]

60. Munns, R.; Tester, M. Mechanisms of salinity tolerance. Annu. Rev. Plant Biol. 2008, 59, 651-681. [CrossRef] [PubMed]

61. Munns, R.; Sharp, R. Involvement of absicic acid in controlling plant growth in soils of low water potential. Aust. J. Plant Physiol. 1993, 20, 425-437.

62. Murguia, J.R.; Belles, J.M.; Serrano, R. A Salt-Sensitive 3'(2'),5'-Bisphosphate Nucleotidase involved in Sulfate activation. Science 1995, 267, 232-234. [CrossRef]

63. Shabala, L.; Mackay, A.; Tian, Y.; Jacobsen, S.E.; Zhou, D.; Shabala, S. Oxidative stress protection and stomatal patterning as components of salinity tolerance mechanism in quinoa (Chenopodium quinoa). Physiol. Plant. 2012, 146, 26-38. [CrossRef] 
64. Maser, P.; Eckelman, B.; Vaidyanathan, R.; Horie, T.; Fairbairn, D.J.; Kubo, M.; Yamagami, M.; Yamaguchi, K.; Nishimura, M.; Uozumi, N.; et al. Altered shoot/root $\mathrm{Na}+$ distribution and bifurcating salt sensitivity in Arabidopsis by genetic disruption of the $\mathrm{Na}+$ transporter AtHKT1. FEBS Lett. 2002, 531, 157-161. [CrossRef]

65. James, R.A.; Munns, R.; von Caemmerer, S.; Trejo, C.; Miller, C.; Condon, A.G. Photosynthetic capacity is related to the cellular and subcellular partitioning of $\mathrm{Na}+, \mathrm{K}+$ and $\mathrm{Cl}-$ in salt-affected barley and durum wheat. Plant Cell Environ. 2006, 29, $2185-2197$. [CrossRef] [PubMed]

66. Chen, Z.; Pottosin, I.I.; Cuin, T.A.; Fuglsang, A.T.; Tester, M.; Jha, D.; Zepeda-Jazo, I.; Zhou, M.; Palmgren, M.G.; Newman, I.A.; et al. Root plasma membrane transporters controlling $\mathrm{K}+/ \mathrm{Na}+$ homeostasis in salt-stressed barley. Plant Physiol. 2007, 145, 1714-1725. [CrossRef] [PubMed]

67. Wullschleger, S.D. Biochemical Limitations to Carbon Assimilation in C3 Plants. A Retrospective Analysis of the j Curves from 109 Species. J. Exp. Bot. 1993, 44, 907-920. [CrossRef]

68. Solomon, A.; Beer, S.; Waisel, Y.; Jones, G.P.; Paleg, L.G. Effects of $\mathrm{NaCl}$ on the carboxylating activity of Rubisco from Tamarix jordanis in the presence and absence of proline-related compatible solutes. Physiol. Plant 1994, 90, 198-204. [CrossRef]

69. Seemann, J.R.; Critchley, C. Effects of salt stress on the growth, ion content, stomatal behaviour and photosynthetic capacity of a salt-sensitive species, Phaseolus vulgaris L. Planta 1985, 164, 151-162. [CrossRef]

70. Wang, Y.; Nii, N. Changes in chlorophyll, ribulose bisphosphate carboxylase-oxygenase, glycine betaine content, photosynthesis and transpiration in Amaranthus tricolor leaves during salt stress. J. Hortic. Sci. Biotechnol. 2000, 75, 623-627. [CrossRef]

71. Seki, M.; Narusaka, M.; Ishida, J.; Nanjo, T.; Fujita, M.; Oono, Y. Monitoring the expression profiles of 7000 Arabidopsis genes under drought, cold and high-salinity stresses using a full-length cDNA microarray. Plant J. 2002, 31, 279-292. [CrossRef] [PubMed]

72. Sobhanian, H.; Razavizadeh, R.; Nanjo, Y.; Ehsanpour, A.A.; Jazii, F.R.; Motamed, N. Proteome analysis of soybean leaves, hypocotyls and roots under salt stress. Proteome Sci. 2010, 8, 19. [CrossRef] [PubMed]

73. Manter, D.K.; Kerrigan, J. A/Ci curve analysis across a range of woody plant species: Influence of regression analysis parameters and mesophyll conductance. J. Exp. Bot. 2004, 55, 2581-2588. [CrossRef]

74. Allakhverdiev, S.I.; Murata, N. Salt stress inhibits photosystems II and I in cyanobacteria. Photosynth. Res. 2008, 98, 529-539. [CrossRef]

75. Feng, Z.T.; Deng, Y.Q.; Zhang, S.C.; Liang, X.; Yuan, F.; Hao, J.L.; Zhang, J.-C.; Sun, S.F.; Wang, B.S. K+ accumulation in the cytoplasm and nucleus of the salt gland cells of Limonium bicolor accompanies increased rates of salt secretion under $\mathrm{NaCl}$ treatment using NanoSIMS. Plant Sci. 2015, 238, 286-296. [CrossRef]

76. Zhao, Y.Q.; Ma, Y.C.; Duan, H.M.; Liu, R.R.; Song, J. Traits of fatty acid accumulation in dimorphic seeds of the euhalophyte Suaeda salsa in saline conditions. Plant Biosyst. 2019, 153, 514-520. [CrossRef]

77. Allakhverdiev, S.I.; Sakamoto, A.; Nishiyama, Y.; Inaba, M.; Murata, N. Ionic and osmotic effects of NaCl-induced inactivation of photosystem I and II in Synechococcus sp. Plant Physiol. 2000, 123, 1047-1056. [CrossRef] [PubMed]

78. Song, Y.; Li, J.; Sui, Y.; Han, G.; Zhang, Y.; Guo, S.; Sui, N. The sweet sorghum SbWRKY50 is negatively involved in salt response by regulating ion homeostasis. Plant Mol. Biol. 2020, 102, 603-614. [CrossRef] [PubMed]

79. Zhang, Q.-Y.; Wang, L.-Y.; Kong, F.-Y.; Deng, Y.-S.; Lia, B.; Meng, Q.-W. Constitutive accumulation of zeaxanthin in tomato alleviates salt stress-induced photoinhibition and photooxidation. Physiol. Plant. 2012, 146, 363-373. [CrossRef]

80. Sui, N.; Han, G.L. Salt-induced photoinhibition of PSII is alleviated in halophyte Thellungiella halophila by increases of unsaturated fatty acids in membrane lipids. Acta Physiol. Plant 2014, 36, 983-992. [CrossRef]

81. Maeda, M.; Sakuragi, Y.; Bryant, D.A.; DellaPenna, D. Tocopherols Protect Synechocystis sp. Strain PCC 6803 from Lipid Peroxidation. Plant Physiol. 2005, 138, 1422-1435. [CrossRef]

82. Tsao, R. Chemistry and Biochemistry of Dietary Polyphenols. Nutrients 2010, 2, 1231-1246. [CrossRef]

83. Escribano, J.; Cabane, J.; Jiménez-Atiénzar, M.; Ibañez-Tremolada, M.; Gómez-Pando, R.L.; García-Carmona, F.; Gandía-Herrero, F. Characterization of betalains, saponins and antioxidant power in differently colored quinoa (Chenopodium quinoa) varieties. Food Chem. 2017, 234, 285-294. [CrossRef]

84. Gomez-Caravaca, A.M.; Segura-Carretero, A.; Fernandez-Gutierrez, A.; Caboni, M.F. Simultaneous determination of phenolic compounds and saponins in quinoa (Chenopodium quinoa Willd) by a liquid chromatography-diode array detection-electrospray ionizationtime- of-flight mass spectrometry methodology. J. Agric. Food Chem. 2011, 59, 10815-10825. [CrossRef] [PubMed]

85. Graf, B.L.; Rojas-Silva, O.; Rojo, L.E.; Delatorre-Herrera, J.; Baldeón, M.E.; Raskin, I. Innovations in Health Value and Functional Food Development of Quinoa (Chenopodium quinoa Willd.). Compr. Rev. Food Sci. Food Saf. 2015, 14, 431-445. [CrossRef]

86. Kurepin, L.V.; Ivanov, A.G.; Zaman, M.; Pharis, R.P.; Hurry, V.; Hüner, N.P.A. Interaction of Glycine Betaine and Plant Hormones: Protection of the Photosynthetic Apparatus During Abiotic Stress. In Photosynthesis: Structures, Mechanisms, and Applications; Hou, H., Najafpour, M., Moore, G., Allakhverdiev, S., Eds.; Springer: Cham, Switzerland, 2017. [CrossRef]

87. Park, S.-Y.; Yu, J.-W.; Park, J.-S.; Li, J.; Yoo, S.-C.; Lee, N.-Y.; Lee, S.-K.; Jeong, S.-W.; Seo, H.-S.; Koh, H.-J.; et al. The SenescenceInduced Staygreen Protein Regulates Chlorophyll Degradation. Plant Cell 2007, 19, 1649-1664. [CrossRef] [PubMed]

88. Chen, T.H.; Murata, N. Glycinebetaine protects plants against abiotic stress: Mechanisms and biotechnological applications. Plant Cell Environ. 2011, 34, 1-20. [CrossRef] [PubMed] 
89. Delatorre-Herrera, J.; Rojas-Urrutia, J.; Rojo, L.E.; Graf, B.L. Osmotic stress in Chenopodium quinoa Willd: Variations in osmoprotectants at different phenological stages. Afr. J. Agric. Res. 2019, 14, 361-368. [CrossRef]

90. Elbein, A.D.; Pan, Y.T.; Pastuszak, I.; Carroll, D. New insights on trehalose: A multifunctional molecule. Glycobiology 2003, 13, 17R-27R. [CrossRef] [PubMed] 